\title{
DIPLOMACIA E POLÍTICA DOMÉSTICA: A LÓGICA DOS JOGOS DE DOIS NÍVEIS
}

\author{
Robert D. Putnam
}

\begin{abstract}
RESUMO
A política doméstica e as relações internacionais com freqüência são inextricavelmente vinculadas; todavia, as teorias existentes (particularmente as estatocêntricas) não levam adequadamente em considerações tais vínculos. Quando os líderes nacionais devem obter as ratificações (formais ou informais) dos membros de seus parlamentos para um acordo internacional, seus comportamentos em negociações refletem os imperativos simultâneos tanto de um jogo de política doméstica quanto de um jogo de política internacional. Usando exemplos de cúpulas econômicas ocidentais, das negociações do Canal do Panamá e do Tratado de Versalhes, dos programas de estabilização do Fundo Monetário Internacional, da Comunidade Européia e de muitos outros contextos diplomáticos, o artigo oferece uma teoria da ratificação. Ele enfatiza o papel das preferências, coalizões, instituições e práticas domésticas, das estratégias e táticas dos negociadores, da incerteza, das reverberações domésticas das pressões externas e o papel dos interesses do negociador-chefe. Essa teoria de "jogos de dois níveis" também pode ser aplicável a muitos outros fenômenos políticos, tais como a dependência, os comitês legislativos e as coalizões multipartidárias.
\end{abstract}

PALAVRAS-CHAVE: jogos de dois níveis; negociações; política interna; política externa; diplomacia.

\section{INTRODUÇÃO: O ENTRELAÇAMENTO DAS POLÍTICAS DOMÉSTICA E INTERNACIO- $\mathrm{NAL}^{2}$}

A política doméstica e as relações internacionais estão sempre entrelaçadas de alguma forma e nossas teorias ainda não desvendaram esse quebra-cabeça. É infrutífero debater se a política doméstica realmente determina as relações internacionais ou se é o inverso. A resposta para essa questão é clara: "Algumas vezes uma influencia a outra". As perguntas mais interessantes são:

\footnotetext{
1 Título original: "Diplomacy and Domestic Politics: The Logic of the Two-Level Games". Publicado originalmente na revista International Organization (Boston, v. 42, n. 3 , p. 427-460, Summer.1988). Tradução de Dalton L. G. Guimarães, Feliciano de Sá Guimarães e Gustavo Biscaia de Lacerda".

2 Uma versão anterior deste artigo foi apresentado em 1986 no encontro anual da American Political Science Association. Pelas críticas e pelas sugestões, estou em débito com Robert Axelrod, Nicholas Bayne, Henry Brady, James A. Coporaso, Barbara Crane, Ernest B. Haas, Stephan Haggard, C. Randal Henning, Peter B. Kenien, Robert O. Keohane, Stephen D. Krasner, Jacek Yu; com os membros de seminários de pesquisa nas universidades de Yowa, Michigan e Harvard e com os dois pareceristas anônimos. Sou grato à Fundação Rockefeller por subvencionar a finalização deste trabalho.
}

“quando influencia?" e “como influencia?". Este artigo oferece uma abordagem teórica para esse tema, mas eu começo com uma história que ilustra o quebra-cabeça.

Um exemplo esclarecedor de como a diplomacia e a política doméstica podem entrelaçar-se aconteceu na Cúpula de Bonn em 1978³. Em meados dos anos 1970, um programa de recuperação global liderado pelas economias "locomotiva" dos Estados Unidos, da Alemanha e do Japão propôs favorecer a recuperação ocidental após o primeiro choque do petróleo 4 . Essa proposta recebeu um forte impulso do iniciante governo Carter, além de ser calorosamente apoiada pelos países mais fracos, pela Organização para Cooperação Econômica e Desenvolvimento (OCDE) e por muitos economistas independentes. Esses economistas argumentavam que o programa superaria os desequilíbrios internacionais das balanças de pagamentos e promoveria o crescimento de to-

\footnotetext{
3 A narrativa a seguir baseou-se nos escritos de Putnam e Henning (1986) e Putnam e Bayne (1987, p. 62-94).

4 Muitos economistas acreditam que entre economias interdependentes as políticas freqüentemente podem ser mais efetivas se forem coordenadas internacionalmente. Para citações relevantes, cf. Putnam e Baynes (1986, p. 24).
} 
dos. Por outro lado, alemães e japoneses protestaram dizendo que não se deveria pedir a administradores econômicos prudentes e bem-sucedidos que salvassem administradores esbanjadores. Ao mesmo tempo, o ambicioso Programa Nacional de Energia de Jimmy Carter permanecia travado no Congresso, enquanto Helmut Schmidt liderava um coro de reclamações sobre o descontrolado apetite americano por petróleo importado e sua aparente despreocupação em relação ao dólar em queda. Todos concordavam que a economia mundial estava em sérias dificuldades, mas não era claro quem deveria ser culpado - se as políticas fiscais restritivas da Alemanha e do Japão ou se as frouxas políticas energética e monetária dos Estados Unidos.

Entretanto, na Cúpula de Bonn um amplo acordo foi aprovado. Foi o caso mais evidente até então de uma cúpula que deixou todos os participantes mais felizes quando saíram do que quando entraram. Helmut Schmidt concordou com estímulos fiscais adicionais na ordem de $1 \%$ do produto nacional bruto (PNB); Jimmy Carter comprometeuse a desregulamentar os preços internos do petróleo por volta do fim de 1980 e Takeo Fukuda prometeu novos esforços para chegar a uma taxa de $7 \%$ de crescimento. Aspectos secundários no acordo de Bonn incluíram ainda a anuência de franceses e britânicos nas negociações comerciais da Rodada de Tóquio ${ }^{5}$; medidas japonesas para fortalecer o crescimento das importações e restringir as exportações e uma promessa genérica dos Estados Unidos de combater a inflação. Ao fim e ao cabo, a Cúpula de Bonn produziu um acordo equilibrado de amplitude e especificidade sem paralelos. E o mais notável foi que virtualmente todos os pontos do pacote foram implementados.

$\mathrm{Na}$ ocasião a maioria dos observadores saudou favoravelmente as políticas adotadas em Bonn, embora tenham ocorrido muitos debates sobre a sabedoria econômica do pacote. Todavia, minha preocupação não é saber se o acordo foi inteligentemente construído, mas como ele tornou-se politicamente viável. Em primeiro lugar, minha pesquisa sugere que governos-chave em Bonn

\footnotetext{
5 A Rodada de Tóquio foi um conjunto de negociações ocorridas entre 1973 e 1979 com vistas à liberalização comercial, no âmbito do General Agreement on Tariffs and Trade (GATT), entidade antecessora da Organização Mundial do Comércio (OMC) (nota do tradutor).
}

adotaram políticas diferentes daquelas que teriam adotado na ausência de negociações internacionais e, em segundo lugar, o acordo só foi possível porque uma poderosa minoria no interior de cada governo apoiou domesticamente a política demandada internacionalmente.

Na Alemanha, um processo político catalisado por pressões externas foi clandestinamente orquestrado por expansionistas do governo Schmidt. Ao contrário da mitologia pública, o acordo de Bonn não foi imposto a uma Alemanha relutante ou "altruísta". Com efeito, funcionários do gabinete do Chanceler e do Ministério da Economia, assim como do Partido Social-Democrata e dos sindicatos, discutiram privadamente no início de 1978 que estímulos internos adicionais eram domesticamente desejáveis, principalmente face às eleições de 1980 , que se aproximavam. Entretanto, eles tinham poucas esperanças de superar a oposição do Ministério das Finanças, do Partido Democrático Livre (membro da coalizão do governo) e das comunidades financeira e de negócios, em particular a liderança do Bundesbank ${ }^{6}$. Publicamente, Helmut Schmidt apresentava-se terminantemente relutante. Somente seus conselheiros mais próximos suspeitavam da verdade: que o Chanceler "deixara-se levar" por uma política que apoiava privadamente, mas que seria custosa e talvez impossível de ser aprovada no plano doméstico sem o acordo da Cúpula.

Situação análoga aconteceu no Japão. Uma coalizão composta por interesses empresariais, pelo Ministério do Comércio e da Indústria (MITI), pela Agência de Planejamento Econômico e por alguns políticos de pensamento expansionista dentro do Partido Democrático Liberal pressionou por estímulos domésticos adicionais usando a pressão dos Estados Unidos como um de seus principais argumentos contra a teimosa resistência do Ministério das Finanças (MOF). Sem as divisões internas de Tóquio era improvável que as demandas externas fossem atendidas, mas sem a pressão externa seria ainda mais improvável que os expansionistas pudessem superar o poderoso MOF. "Setenta por cento de pressão externa, 30\% política interna" foi o diagnóstico de um desapontado membro do MOF. "Meio a meio", sugeriu um funcionário do $\mathrm{MITI}^{7}$.

\footnotetext{
6 Banco Central alemão (N. T.).

7 Para uma narrativa abrangente da história japonesa, cf. Destler e Mitsuyu (1982).
} 
No caso dos Estados Unidos, a atividade política interna também reforçou e foi reforçada pela pressão internacional. Durante a preparação para a Cúpula os negociadores estadunidenses convidaram suas contrapartes internacionais a colocar mais pressão sobre os norte-americanos com o intuito de reduzir a importação de petróleo. Funcionários-chave da área econômica do governo apoiavam uma política de energia mais dura, mas sofriam oposição dos assessores políticos mais próximos do Presidente, mesmo depois da Cúpula. Além disso, adversários no Congresso continuavam a bloquear a desregulamentação do preço interno do petróleo, como haviam feito tanto sob Ford como sob Nixon. Finalmente, em abril de 1979, o Presidente decidiu-se por uma desregulamentação administrativa gradual, levantando os preços dos EUA para os níveis mundiais por volta de outubro de 1981. Assim, seus assessores domésticos conseguiram adiar um ato politicamente custoso para depois da eleição presidencial de 1980, mas no final virtualmente todos os compromissos assumidos em Bonn foram cumpridos. Tanto os proponentes quanto os adversários da desregulamentação concordaram que os compromissos da Cúpula estavam no centro do aquecido debate intramuros do governo durante $\mathrm{o}$ inverno de 1978-1979 e que foram instrumentais para a decisão final ${ }^{8}$.

Em suma, o acordo de Bonn representou uma genuína coordenação política internacional. Mudanças significativas de política foram prometidas e implementadas pelos participantes-chave. Mais do que isso - e ainda que este argumento contrafactual seja necessariamente mais difícil de estabelecer -, essas mudanças de política provavelmente não teriam sido alcançadas (certamente não na mesma escala e no mesmo espaço de tempo) na ausência do acordo internacional. Em cada país, uma faç̧ão apoiou a mudança política demandada ao seu país internacionalmente, mas essa facção era inicialmente minoritária. Assim, a pressão internacional foi uma condição necessária para que essas mudanças de políticas. Por outro lado, sem uma ressonância doméstica, as forças internacionais não teriam sido suficientes para produzir o acordo, não importando quão equilibrado e intelectualmente persuasivo fosse o pacote geral.

\footnotetext{
8 Para uma narrativa excelente da política de energia dos
} EUA durante esse período, cf. Ikenberry (1988).
No fim, cada líder acreditava que o que fazia era no interesse da nação - e provavelmente também no seu próprio interesse, embora nem todos os seus auxiliares concordassem ${ }^{9}$. Entretanto, sem o acordo da Cúpula os líderes provavelmente não teriam alterado (ou não poderiam alterar) as políticas econômicas tão facilmente. Nesse sentido, o acordo de Bonn combinou com sucesso as pressões domésticas e as internacionais.

Nem uma análise puramente doméstica nem uma puramente internacional poderia abordar esse episódio. As interpretações baseadas em causas domésticas e efeitos internacionais ("segunda imagem" (WALTZ, 1959)) ou em causas internacionais e efeitos domésticos ("segunda imagem invertida" (GOUREVITCH, 1978)) representariam meras análises de "equilíbrio parcial" e omitiriam uma importante parte da história, qual seja, como as políticas domésticas de diversos países tornaramse entrelaçadas por meio de uma negociação internacional. Os eventos de 1978 ilustram que, em vez dessas análises parciais, devemos voltar a atenção para teorias de "equilíbrio geral" que dêem conta simultaneamente das interações de fatores domésticos e internacionais. Este artigo sugere uma estrutura conceitual para entender-se como a diplomacia e a política doméstica interagem.

\section{OS ENTRELAÇAMENTOS ENTRE O DO- MÉSTICO E O INTERNACIONAL: O ESTA- DO DAARTE}

Muito da literatura existente sobre as relações entre questões domésticas e internacionais consiste ou em listas ad hoc de incontáveis "influências domésticas" sobre a política externa ou em observações genéricas sobre questões nacionais e internacionais que estão de alguma forma "vinculadas" 10 . James Rosenau foi um dos primeiros pesquisadores a chamar atenção para essa área, porém sua elaborada taxonomia de "vínculos entre questões" (linkage politics) gerou pouca pesquisa cumulativa, exceto por uma repentina leva de trabalhos correlacionando "comportamentos

\footnotetext{
9 Não está claro se Jimmy Carter entendeu completamente as implicações domésticas do seu compromisso em Bonn nessa ocasião (cf. PUTNAM \& HENNING, 1986; IKENBERRY, 1988).

10 Estou em débito com Stephan Haggad pelas esclarecedoras discussões a respeito das influências domésticas nas relações internacionais.
} 
conflitantes" doméstico e internacional (ROSENAU, 1969; 1973, especialmente p. 49).

Uma segunda corrente relevante de teorização iniciou-se com os trabalhos de Karl Deutsch e Ernst Haas sobre integração regional (DEUTSCH, 1957; HAAS, 1958). Haas, em particular, enfatizou o impacto dos partidos e dos grupos de interesse no processo de integração européia e sua noção de "transbordamento" reconheceu a mútua influência entre desenvolvimentos domésticos e internacionais. Entretanto, a variável dependente central desse trabalho era a hipotética evolução de novas instituições supranacionais, em vez de desenvolvimentos específicos de políticas públicas e quando a integração européia atolou-se, também se atolou essa literatura. Os herdeiros intelectuais desta tradição, como Joseph Nye Jr. e Robert Keohane, enfatizaram a interdependência e o transnacionalismo, mas o papel dos fatores domésticos escapou mais e mais do foco, principalmente quando o conceito de regimes internacionais passou a dominar o subcampo (KEOHANE \& NYE JR., 1977) ${ }^{11}$.

A escola de análise da política externa da "política burocrática" iniciou um outro promissor ataque sobre o problema da interação entre o doméstico e o internacional. Como Grahan Allison apontou, "Aplicada às relações entre nações, o modelo da política burocrática volta suas atenções para os jogos intranacionais, a sobreposição dos quais constitui as relações internacionais" (ALLISON, 1971, p. 149). No entanto, a natureza dessa "sobreposição" manteve-se obscura e a contribuição teórica dessa literatura não evoluiu muito além do princípio segundo o qual os interesses burocráticos importam para a elaboração da política externa.

Mais recentemente, o trabalho mais sofisticado sobre os determinantes domésticos da política externa focalizou fatores "estruturais", particularmente a "força do Estado". As pesquisas capitais de Peter Katzenstein e Stephen Krasner, por exemplo, mostraram a importância dos fatores domésticos para a política econômica externa. Katzenstein captou a essência do problema: "O objetivo principal de todas as estratégias de política econômica externa é tornar as políticas domésticas compatíveis com a economia política

\footnotetext{
11 A respeito da literatura sobre regimes, incluindo sua negligência relativamente aos fatores domésticos, cf. Haggard e Simmons (1987).
}

internacional" (KATZENSTEIN, 1978, p. 4; cf. também KATZENSTEIN, 1976; KRASNER, 1978a; 1978b). Ambos os autores enfatizam o ponto crucial segundo o qual os formuladores centrais de políticas ("o Estado") devem simultaneamente se preocupar com as pressões doméstica e internacional.

Mais discutível, entretanto, é sua identificação da "força do Estado" como a variável-chave de interesse. Dadas as dificuldades de medir-se a "força do Estado", tal abordagem incorre em uma tautologia 12 e os esforços para determinar a posição de cada país nesse ambíguo contínuo mostraram-se problemáticos (MILNER, 1987). A “força do Estado", se reinterpretada meramente como o oposto da fragmentação governamental, sem dúvida tem algum interesse para o estudo comparativo da política externa. Todavia, Gourevitch está razoavelmente correto ao reclamar que "o argumento Estado forte-Estado fraco sugere que [...] a identidade da coalizão governante não importa. Esse é um argumento muito apolítico" (GOUREVITCH, 1978, p. 903). Além disso, como as "estruturas do Estado" (como concebido por essa literatura) variam pouco de caso a caso ou de ano a ano, tais explicações são pouco adequadas para explicar as diferenças entre os temas ou ao longo do tempo (exceto se o "tempo" for medido em décadas ou séculos). Uma concepção mais adequada dos determinantes domésticos da política externa e das relações internacionais deve enfatizar a luta politica: os partidos, as classes sociais, os grupos de interesse (tanto econômicos quanto não-econômicos), os legisladores e mesmo a opinião pública e as eleições - e não apenas os funcionários do poder Executivo e os arranjos institucionais ${ }^{13}$.

Algumas pesquisas do gênero "estatocêntrico" apresentam um modelo de ator unitário fora de controle. "A proposição central deste ensaio",

\footnotetext{
12 Por exemplo, cf. Krasner (1978b, p. 55): “A característica analítica central que determina a capacidade de um Estado de superar a resistência doméstica é sua força em relação à sua própria sociedade"

13 Em seus trabalhos mais descritivos, os pesquisadores "estatocêntricos" são normalmente sensíveis aos impactos dos conflitos sociais e políticos, como os entre indústria e finanças, trabalho e negócios e setores exportadores versus setores importadores (cf. KATZENSTEIN, 1978, p. 333336).
} 
aponta um estudo recente, "é que o Estado deriva seus interesses do sistema internacional e defende políticas consistentes com esse sistema em qualquer momento e sob quaisquer circunstâncias" (LAKE, 1984, p. 13). Na verdade, em quase todas as questões importantes, os "tomadores centrais de decisão" discordam a respeito do que o interesse nacional e o contexto internacional demandam. Mesmo se arbitrariamente excluirmos o poder Legislativo do "Estado" (como faz essa literatura), é errado pressupor que o poder Executivo é coeso em suas opiniões. Certamente isso não foi verdade para nenhum dos estados envolvidos nas negociações de 1978. Qual era "a" posição do Estado alemão ou japonês na política macroeconômica em 1978 ou a do Estado norteamericano na política energética? Se o termo "Estado" é para ser usado como "tomadores centrais de decisões", deveríamos tratá-lo como substantivo plural: não "o Estado, ele", mas sim “o Estado, eles". Os poderes executivos centrais têm um papel especial na mediação das pressões domésticas e internacionais exatamente porque estão diretamente expostos a ambas as esferas e não porque sejam unificados em todas questões ou porque estejam insulados em relação à política doméstica.

Assim, a literatura estatocêntrica não tem bases para a teorização sobre como as políticas doméstica e internacional interagem. Mais interessantes são os recentes trabalhos sobre o impacto da economia internacional sobre a política doméstica e a política econômica doméstica, como os de Alt, Evans, Gourevitch e Katzenstein (EVANS, 1979; KATZENSTEIN, 1985; GOUREVITCH, 1986; ALT, 1987). Esses estudos de casos, baseados em diversas abordagens metodológicas, exibem uma sofisticação teórica sobre a relação causal do internacional sobre o doméstico muito maior do que é característico dos estudos comparáveis sobre a relação do doméstico sobre o internacional. Ainda assim, essas pesquisas não pretendem dar conta de exemplos de causalidade recíproca e muito menos examinam casos nos quais as políticas domésticas de diversos países tornam-se entrelaçadas internacionalmente.

Em suma, precisamos ir para além da mera observação de que os fatores domésticos influenciam os assuntos internacionais e vice-versa, assim como dos meros catálogos de situações em que ocorrem essas influências, a fím de buscar teorias que integrem ambas as esferas, levando em consideração as áreas de entrelaçamento entre elas.

\section{JOGOS DE DOIS NÍVEIS: UMA METÁFO- RA PARAAS INTERAÇÕES DOMÉSTICO- INTERNACIONAL}

Há mais de duas décadas Richard E. Walton e Robert B. McKersie criaram uma "teoria comportamental" das negociações sociais que é notavelmente aplicável para os conflitos e cooperação internacionais (WALTON \& MCKERSIE, 1965). Eles mostraram, como todo negociador experiente, que o pressuposto do ator unitário é com freqüência radicalmente enganoso. Como disse Robert Strauss a respeito da Rodada de Tóquio, "Durante meu mandato como Representante Especial de Comércio [dos Estados Unidos], gastei tanto tempo negociando com grupos domésticos (industriais e trabalhistas) e com membros do Congresso dos Estados Unidos quanto gastei negociando com nossos parceiros comerciais estrangeiros" (STRAUS, 1987, p. vii).

A luta política de várias negociações internacionais pode ser utilmente concebida como um jogo de dois níveis. No nível nacional, os grupos domésticos perseguem seu interesse pressionando o governo a adotar políticas favoráveis a seus interesses e os políticos buscam o poder constituindo coalizões entre esses grupos. No nível internacional, os governos nacionais buscam maximizar suas próprias habilidades de satisfazer as pressões domésticas, enquanto minimizam as conseqüências adversas das evoluções externas. Nenhum dos dois jogos pode ser ignorado pelos tomadores de decisão, pois seus países permanecem ao mesmo tempo interdependentes e soberanos.

Cada líder político nacional está presente em ambos os tabuleiros. Do outro lado do tabuleiro internacional sentam as contrapartes estrangeiras, ao lado das quais sentam diplomatas e outros assessores internacionais. Em volta do tabuleiro doméstico e atrás do líder nacional, sentam-se figuras partidárias, parlamentares, porta-vozes das agências domésticas, representantes de gruposchave de interesses e os assessores políticos do próprio líder. A incomum complexidade desse jogo de dois níveis torna-se clara quando ações que são racionais para um jogador em determinado tabuleiro (como aumentar os preços da energia, conceder território ou limitar a importação de carros) podem ser imprudentes para esse mesmo jo- 
gador em outro tabuleiro. Entretanto, existem poderosos incentivos para que haja coerência entre esses dois jogos. Os jogadores (e observadores) tolerarão algumas diferenças retóricas entre os dois jogos, mas no final ou os preços da energia aumentam ou não.

As complexidades políticas para os jogadores neste jogo de dois níveis são impressionantes. Qualquer jogador importante do tabuleiro internacional que estiver insatisfeito com o resultado pode desorganizar o jogo e, inversamente, qualquer líder que não consiga satisfazer seus companheiros do tabuleiro doméstico arrisca ser retirado de seu assento. Entretanto, às vezes jogadores mais capazes identificam movimentações em determinado tabuleiro que desencadeiam realinhamentos em outro, permitindo-lhes atingir objetivos que não conseguiriam de outra maneira. Essa metáfora de "dois tabuleiros" apreende melhor as dinâmicas das negociações de 1978 do que qualquer outro modelo baseado em atores nacionais unitários.

Outros estudiosos notaram a natureza de jogos múltiplos das relações internacionais. Assim como Walton e McKersie, Daniel Druckman observou que o negociador "busca construir um pacote que seja aceito tanto pelo outro lado como por sua própria burocracia". Entretanto, Druckman modela os processos doméstico e internacional separadamente e conclui que "a interação entre os processos [...] permanece um tópico para investigação [futura]" (DRUCKMAN, 1978, p. 100101, 109). Roberto Axelrod propôs um "paradigma gama" no qual o Presidente dos Estados Unidos persegue determinadas políticas vis-à-vis a União Soviética ${ }^{14}$, mas com um olho voltado para a maximização de sua popularidade doméstica. Contudo, esse modelo desconsidera divisões internas e postula que um dos atores internacionais - a liderança soviética - somente se preocupa com ganhos internacionais sem sofrer restrições domésticas, enquanto o outro - o Presidente estadunidense - preocupa-se apenas com ganhos domésticos, exceto quando seu público interno leva em consideração a competição internacional (AXELROD, 1987). Provavelmente, a teoria empiricamente baseada mais interessante a respeito da conexão entre as barganhas doméstica e

14 Convém lembrar que o presente artigo foi publicado em 1988, portanto durante a época em que existia a União Soviética e ocorria a Guerra Fria (N. T.). internacional é de Glenn Snyder e Paul Diesing. Ainda que trabalhando na tradição neo-realista com sua concepção convencional de atores unitários, os autores descobriram que, em metade das crises que investigaram, os principais tomadores de decisão não eram unificados. Eles concluíram que a previsão sobre resultados internacionais melhora significativamente ao compreender-se as barganhas internas, especialmente em relação a compromissos minimamente aceitáveis (SNYDER \& DIESING, 1977, p. 510-525).

Metáforas não são teorias, mas fico feliz com a observação de Max Black segundo a qual "talvez toda ciência devesse começar com uma metáfora e terminar com álgebra; talvez sem metáfora jamais haveria qualquer álgebra" (Black apud SNIDAL, 1985, p. 36n.). A análise formal de qualquer jogo exige regras bem definidas, escolhas, ganhos, jogadores e informação e, ainda assim, muitos dos jogos simples de duas pessoas com motivações múltiplas não têm solução determinada. Elaborar soluções analíticas a partir de jogos de dois níveis será um desafio difícil. Nas próximas seções espero incentivar mais estudos sobre esse problema.

\section{EM DIREÇÃO A UMA TEORIA DA RATIFI- CAÇÃO: A IMPORTÂNCIA DOS “WIN- SETS"}

Considere-se o seguinte cenário estilizado que pode ser aplicado a qualquer jogo de dois níveis. Negociadores que representam duas organizações encontram-se para buscar um acordo entre si, sujeitos à limitação de que qualquer acordo provisório precisa ser ratificado pelas respectivas organizações. Os negociadores podem ser, por exemplo, chefes de governo, representantes dos trabalhadores e dos empresários, líderes partidários de uma coalizão política, um ministro das finanças negociando com uma equipe do Fundo Monetário Internacional (FMI), líderes de um comitê misto Câmara dos Deputados-Senado ${ }^{15}$ ou líderes de grupos étnicos de uma democracia consociativis-

\footnotetext{
15 Convém notar que as expressões "Câmara dos Deputados" e "Senado", usadas ao longo deste artigo, referem-se aos órgãos legislativos específicos dos Estados Unidos (respectivamente: "House of Representatives" e "Senate", em inglês); desse modo, não são órgãos genéricos utilizados pelo autor para efeitos de argumentação. O mesmo aplicase à expressão "congressista" ("congressmen" ou “congresswoman") (N. T.).
} 
ta. Por enquanto, devemos presumir que cada lado é representado por um único líder ou "negociador-chefe" e que esse indivíduo não tem preferências políticas independentes, mas que busca simplesmente encontrar um entendimento que será atrativo para suas bases ${ }^{16}$.

É conveniente dividirmos analiticamente o processo em dois estágios:

1. a barganha entre os negociadores que leva a um acordo provisório - chamemos este estágio de nível I;

2. as discussões em separado entre os grupos domésticos de apoio sobre ratificar ou não o acordo - chamemos este estágio de nível II.

Essa divisão seqüencial em uma fase de negociação e uma fase de ratificação é útil para a explicação, embora não seja acurada em termos descritivos. Na prática, os efeitos das expectativas serão bastante importantes. É bem provável que haja consultas prévias e barganhas no nível II com o objetivo de elaborar uma posição inicial para o nível I. Contrariamente, a necessidade de ratificação do nível II certamente afeta as barganhas do nível I. Na verdade, as expectativas de rejeição no nível II podem abortar as negociações no nível I sem nenhuma ação formal no nível II. Por exemplo, mesmo que os governos do Irã e dos Estados Unidos tenham aparentemente apoiado um acordo que trocava armas por reféns, as negociações entraram em colapso tão logo se tornaram públicas e sujeitas a uma "ratificação" de facto. Em muitas negociações, o processo de dois níveis pode ser iterativo à medida que os negociadores tentam diferentes acordos e sondam os pontos de vista de suas bases. Em casos mais complicados, como veremos adiante, os pontos de vista das bases podem evoluir ao longo das negociações. No entanto, o requisito de que qualquer acordo no nível I precisa ser, ao final, ratificado no nível II impõe uma ligação teórica crucial entre os dois níveis.

A "ratificação" pode envolver um processo formal de votação no nível II, como os dois terços

\footnotetext{
16 A fim de evitar uma complexidade desnecessária, meu argumento será totalmente elaborado em termos de apenas um negociador-chefe, embora em muitos casos algumas de suas responsabilidades possam ser delegadas para auxiliares. Adiante neste artigo eu atenuo o pressuposto de que o negociador não tem preferências independentes.
}

de votos constitucionalmente necessários no Senado dos Estados Unidos para a ratificação de tratados, mas eu uso o termo genericamente me referindo a qualquer processo decisório no nível II que seja necessário para endossar ou implementar um acordo formal ou informal do nível I. Às vezes é conveniente pensar na ratificação como uma função parlamentar, mas isso não é essencial. Os atores do nível II podem representar agências burocráticas, grupos de interesse, classes sociais ou mesmo a "opinião pública". Por exemplo, se sindicatos trabalhistas de um país devedor recusa a necessária cooperação a um programa de austeridade que o governo tenha negociado com o FMI, pode-se dizer que a ratificação do acordo no nível II falhou. As expectativas ex ante em torno dessa possibilidade certamente influenciarão as negociações do nível I entre o governo e o FMI.

A ratificação doméstica de acordos internacionais pode ser peculiar às democracias. Como o Ministro das Finanças alemão observou recentemente, "O limite da cooperação expandida reside nos fatos de que somos democracias e de que precisamos assegurar maioria eleitoral em casa" (Stoltenberg apud HENNING, 1987, p. 1). Entretanto, a ratificação não precisa ser "democrática" em qualquer sentido normal. Por exemplo, em 1930 a Constituição Meiji foi interpretada de modo a atribuir um papel especial aos militares japoneses na ratificação do Tratado Naval de Londres (TAKASHI, 1970; TATSUO, 1984, p. 11-117) ${ }^{17}$; durante a ratificação de qualquer tratado entre católicos e protestantes na Irlanda do Norte presumivelmente o Exército Republicano Irlandês (IRA) mostraria sua força influenciando o processo. Precisamos somente estipular que, para fins de contagem de "votos" no processo de ratificação, pode-se reduzir diferentes formas de poder político a algum denominador comum.

A única restrição formal no processo de ratificação é que, já que acordos idênticos precisam ser ratificados por ambos os lados, um acordo preliminar do nível I não pode ser emendado no nível II sem reabrir as negociações do nível I. Em outras palavras, a ratificação final só pode ser "votada" a favor ou contra; qualquer modificação no nível I conta como rejeição, a menos que essa

17 Estou em dívida com William Jarosz por esse exemplo. 
modificação seja aprovada por todas as outras partes do acordo ${ }^{18}$. A Congressista Lynn Martin compreendeu a lógica da ratificação ao explicar o seu apoio ao projeto de lei da reforma tributária de 1986 que chegou ao comitê misto: "Ainda que eu esteja preocupada com o que esta lei promove, eu estou ainda mais preocupada com o código atual. A escolha, hoje, não é entre este projeto e um projeto de lei perfeito; a escolha é entre este projeto e a morte da reforma tributária" (Martin apud ROSENBAUM, 1986).

Dado esse conjunto de arranjos institucionais, podemos definir o "conjunto de vitórias" [winset] para determinada base de apoio do nível II como o conjunto de todos os acordos possíveis do nível I que seriam vitoriosos - ou seja, que alcançariam a maioria necessária entre os apoiadores - quando colocados em votação ${ }^{19}$. Por duas razões bem diferentes, os contornos dos conjuntos de vitórias do nível II são muito importantes para entender-se os acordos do nível I.

Em primeiro lugar, maiores conjuntos de vitórias tornam os acordos no nível I mais prováveis, coteris paribus ${ }^{20}$. Por definição, qualquer acordo bem-sucedido precisa encaixar-se nos conjuntos de vitórias do nível II de cada uma das partes do acordo. Assim, o acordo somente é possível se esses conjuntos de vitórias sobrepuserem-se; quanto maior cada conjunto de vitórias, mais provável é a sobreposição. Inversamente, quanto menores forem os conjuntos de vitórias, maior é o risco de as negociações fracassarem. Por exemplo, durante as prolongadas negociações prévias ao conflito anglo-argentino sobre as Ilhas Malvinas, diversos acordos provisórios foram re-

\footnotetext{
18 Essa condição, de fato, é característica da maioria dos procedimentos de ratificações do mundo real, como no caso das ações da Câmara dos Deputados e do Senado a respeito dos relatórios dos comitês mistos, embora isso seja em parte violado pela prática ocasional de anexar "reservas" à ratificação dos tratados.

19 Para a concepção de conjunto de vitórias, cf. Shepsle e Weingast (1987). Estou em débito com o Professor Shepsle pela grande ajuda nesse tópico.

20 Para evitar o tédio, não repito a cláusula "as outras coisas mantendo-se iguais" [cláusula cœteris paribus] em cada uma das proposições que se seguem. Sob algumas circunstâncias um conjunto expandido de vitórias poderia na verdade tornar factível algum resultado que disparasse um dilema de ação coletiva (cf. CRAWFORD, 1982).
}

jeitados em uma capital ou outra por motivos de política doméstica; quando se tornou claro que os conjuntos iniciais de vitórias britânicos e argentinos não se sobrepunham de maneira alguma, a guerra tornou-se virtualmente inevitável (DABAT \& LORENZANO, 1984; HASTINGS \& JENKINS, 1984; THE SUNDAY TIMES INSIGHT TEAM, 1982) ${ }^{21}$.

Uma digressão curta, porém importante: a possibilidade de uma ratificação fracassada sugere que a analise teórica do jogo deveria distinguir entre defecção voluntária e involuntária. A defecção voluntária refere-se a uma recusa dada por um ator egoísta racional na ausência de contratos obrigatórios - por exemplo, o problema constantemente analisado do dilema do prisioneiro e outros dilemas de ação coletiva. A defecção involuntária, por outro lado, reflete o comportamento de um agente que é incapaz de cumprir uma promessa devido ao fracasso de uma ratificação. Mesmo que esses dois tipos de comportamento sejam difíceis de distinguir em algumas situações, suas lógicas básicas são bem diferentes.

As perspectivas para cooperação internacional em um mundo anárquico e de "auto-ajuda" são freqüentemente consideradas desfavoráveis porque "infelizmente os tomadores de decisão geralmente têm incentivos para trapacear" (CANZONERI \& GRAY, 1983). Todavia, como Axelrod, Keohane e outros indicaram, a tentação de defecção pode ser dramaticamente reduzida entre jogadores que esperam encontrar-se novamente no futuro (AXELROD, 1984; KEOHANE, 1984, especialmente p. 116; WORLD POLITICS, 1985). Se os tomadores de decisão em um mundo anárquico estivessem constantemente tentados a trapacear, certas características da história de 1978 seriam bastante anômalas. Por exemplo, embora o acordo de Bonn tenha sido negociado com extremo cuidado, não havia provisões para equilíbrio temporário, seqüenciamento ou condições parciais, os quais poderiam ter protegido as partes contra a defecção inesperada. Além disso, alemães e japoneses aprovaram de modo irrevogável suas partes do acordo mais de seis meses antes da ação do Presidente dos Estados Unidos de desregulamentação do preço do petróleo e cerca de dois anos antes de a medida ser

21 Estou em débito com Louise Richardson por essas citações. 
implementada. Uma vez feito isso, a tentação do Presidente de rejeitar a proposta de Bonn deve ter sido avassaladora, mas virtualmente ninguém nos dois lados do debate sobre a desregulamentação dentro do governo estadunidense descartou o compromisso de Bonn como algo irrelevante. Resumindo, a "promessa" de Bonn tinha peso político, porque a rejeitar acarretaria altos custos político e diplomático.

Por outro lado, em qualquer jogo de dois níveis a credibilidade de um compromisso oficial pode ser baixa, mesmo que custos reputacionais da rejeição sejam altos, pois o negociador pode ser incapaz de garantir a ratificação. $O$ insucesso do Congresso em ratificar a abolição do "Preço de Venda Americano" [American Selling Price] como foi previamente acordado nas negociações comerciais da Rodada Kennedy é um caso clássico. Outro caso foi a inabilidade do Primeiro-Ministro japonês Sato de cumprir uma promessa feita ao Presidente Nixon durante a "Disputa Têxtil" [Textile Wrangle] (DESTLER, FUKUI \& SATO, 1979, p. 121-157) ${ }^{22}$. Por fim, um importante obstáculo à coordenação econômica entre os países ocidentais em 1985-1987 era o temor alemão de que o governo Reagan fosse politicamente incapaz de cumprir qualquer compromisso que implicasse diminuição do déficit orçamentário estadunidense, não importando quão bem intencionado fosse o Presidente.

Ao contrário das preocupações com a defecção voluntária, a preocupação com a "habilidade para executar" foi um elemento relevante nas negociações de Bonn. Na conferência de imprensa após a Cúpula, o Presidente Carter enfatizou que "cada um de nós foi cuidadoso em não prometer mais do que podemos executar". Uma questão

22 O American Selling Price foi um regime estadunidense de taxação de importações criado em 1922, na Lei de Tarifas Fordney-McCumber; de acordo com ele, um produto importado seria tarifado de acordo com os preços dos produtos congêneres nacionais e não de acordo com o valor originário do bem. À semelhança da Rodada Tóquio, a Rodada Kennedy foi um conjunto de negociações realizado no âmbito do GATT; nesse caso em particular, tais negociações ocorreram entre 1964 e 1967. A Textile Wrangle foi uma disputa entre os Estados Unidos e o Japão ocorrida entre 1969 e 1971, em que os Estados Unidos afirmaram que seu setor têxtil, em particular o lanífero, estava ameaçado pela produção japonesa; o resultado foi a imposição de barreiras comerciais à importação, pelos Estados Unidos, de têxteis (sintéticos, de lã, de algodão) (N. T.). central ao longo das negociações era a capacidade de Carter de fazer valer seus compromissos na área de energia. Os estadunidenses trabalharam arduamente para convencer os demais negociadores de que, em primeiro lugar, o Presidente estava sob severas restrições políticas domésticas na área de energia, o que limitava o que poderia prometer, mas, em segundo lugar, que ele poderia executar aquilo ele estava preparado para promoter. Os negociadores em 1978 pareceram seguir esta idéia a respeito uns dos outros: "Ele fará o que prometeu desde que aquilo que foi prometido seja claro e dentro de seu poder".

A defecção involuntária, e o medo dela, pode ser tão fatal para as expectativas de cooperação quanto a defecção voluntária. Além disso, em alguns casos pode ser difícil tanto para o outro lado como para os analistas externos distinguir a defecção voluntária da involuntária, particularmente se um negociador estratégico tentar representar uma defecção voluntária como involuntária. Esse comportamento é presumivelmente sujeito a certas restrições reputacionais, embora seja uma importante questão empírica analisar o quão longe as reputações podem ser generalizadas da coletividade para os negociadores e vice-versa. A credibilidade (e, portanto, a capacidade de obter acordos) no nível I é acentuada pela capacidade comprovada do negociador em "executar" no nível II. Essa foi a grande força de Robert Strauss nas negociações da Rodada de Tóquio (WINHAM, 1980, p. 377-397; 1986).

A defecção involuntária somente pode ser entendida dentro da estrutura de um jogo de dois níveis. Assim, voltando ao assunto dos conjuntos de vitórias, quanto menores os conjuntos de vitórias, maior é o risco de defecção involuntária e, portanto, mais aplicável é a literatura sobre dilemas de ação coletiva ${ }^{23}$.

A segunda razão pela qual o tamanho do conjunto de vitórias é importante é que os tamanhos relativos dos respectivos conjuntos de vitórias do nível II afetarão a distribuição de ganhos conjuntos das barganhas internacionais. Quanto mais

\footnotetext{
23 Essa discussão pressupõe implicitamente a incerteza quanto aos contornos dos conjuntos de vitórias por parte dos negociadores do nível I; afinal, se os conjuntos de vitórias fossem conhecidos com certeza, os negociadores nunca proporiam para ratificação um acordo que pudesse ser rejeitado
} 
as partes do nível I perceberem o conjunto de vitórias do negociador como um conjunto amplo, mais ele poderá ser pressionado pelos demais negociadores. Por outro lado, um pequeno conjunto de vitórias doméstico pode ser uma vantagem na negociação: "Eu gostaria de aceitar a sua proposta, mas eu jamais conseguiria que ela fosse aceita em casa". Lamentar as restrições domésticas sob as quais alguém tem que operar (nas palavras de um experiente diplomata britânico) "é a coisa natural a dizer no começo de uma dura negociação" (Harrison apud CAMPBELL, 1976, p. 62).

Esse princípio geral foi, naturalmente, notado pela primeira vez por Thomas Schelling quase 30 anos atrás: "O poder de um negociador freqüentemente repousa em sua incapacidade evidente de fazer concessões e satisfazer demandas [...]. Quando o governo dos Estados Unidos negocia com outros governos [...], se o poder Executivo negocia sob uma autoridade delegada pelo poder Legislativo, sua posição de negociação acaba sendo controlada pela lei, [...] então o Executivo tem uma posição firme que é visível para os demais negociadores [...]. (Sem dúvida estratégias como essa) correm o risco de criar uma posição imobilizada que vai além da capacidade do outro de conceder e, portanto, aumenta as chances de impasse e rompimento" (SCHELLING, 1960, p. 19-28).

Escrevendo sob o ponto de vista de um estrategista, Schelling enfatiza as formas pelas quais os conjuntos de vitórias podem ser manipulados, mas mesmo quando o tamanho do conjunto está além do controle do negociador, este último poderá explorar sua influência. Um líder do Terceiro Mundo cuja posição doméstica é relativamente fraca (a Argentina de Raul Alfonsín?) deveria ser capaz de conduzir melhor uma negociação com seus credores internacionais, todos os outros fatores mantendo-se constantes, do que aquele cuja posição doméstica é mais sólida (o México de Miguel de la Madrid?) ${ }^{24}$. As dificuldades de alcançar a ratificação pelo Congresso são geralmente exploradas pelos negociadores estadunidenses. Durante as negociações do Tratado do Canal do Panamá, por exemplo, “o Secretário de Estado alertou os panamenhos várias vezes [...] de que o

\footnotetext{
24 Sou grato a Lara Putnam por esse exemplo. Para evidências que corroboram esse exemplo, cf. Kaufman (1985, p. 473-503).
}

novo tratado tinha que ser aceitável pelo menos para 67 senadores"; "Carter, em uma carta pessoal para Torrijos, alertou que concessões adicionais dos Estados Unidos ameaçariam seriamente as possibilidades de ratificação pelo Senado" (HABEED \& ZARTMAN, 1986, p. 40, 42). Precisamente para evitar essas táticas, os oponentes podem pedir que um negociador assegure para si alguma "margem de negociação" no nível II antes de iniciar as negociações do nível I.

As implicações ambíguas ["sweet-and-sour"] do tamanho do conjunto de vitórias estão resumidas na Figura 1, que representa um jogo de soma zero simples entre $\mathrm{X}$ e $\mathrm{Y}$.

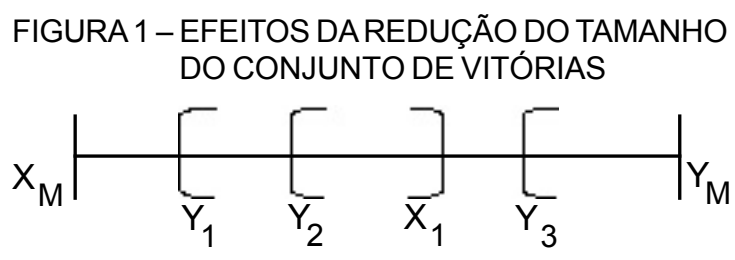

As siglas $\mathrm{X}_{\mathrm{M}}$ e $\mathrm{Y}_{\mathrm{M}}$ representam os resultados máximos respectivamente para $\mathrm{X}$ e $\mathrm{Y}$, enquanto $\mathrm{X}_{1}$ e $\mathrm{Y}_{1}$ representam o resultado mínimo que poderia ser ratificado. Nesse estágio qualquer acordo na distância entre $\mathrm{X}_{1}$ e $\mathrm{Y}_{1}$ poderia ser ratificado por ambas as partes. Se o conjunto de vitórias de $\mathrm{Y}$ fosse reduzido, digamos, para $\mathrm{Y}_{2}$ (talvez por demandar u'a maioria mais ampla para ratificação) os resultados entre $Y_{1}$ e $Y_{2}$ não seriam mais viáveis e o leque de acordos viáveis seria, portanto, reduzido em favor de Y. Entretanto, se Y, encorajado por esse sucesso, reduzisse ainda mais seu conjunto de vitórias para além de $\mathrm{Y}_{3}$ (talvez ao requerer unanimidade para a ratificação), os negociadores repentinamente se veriam em um impasse, pois os conjuntos de vitórias não seriam mais sobrepostos ${ }^{25}$.

25 Diversos pesquisadores de outros campos propuseram
modelos de jogos interligados semelhantes ao jogo de "dois
níveis". Kenneth A. Shepsle e seus colegas utilizaram a
noção de "jogos interconectados" para analisar, por exem-
plo, a estratégia de um legislador simultaneamente envolvi-
do em dois jogos - na arena legislativa e na arena eleitoral.
Nesse modelo, uma determinada ação é simultaneamente
um movimento em dois jogos diferentes e um jogador
maximiza a soma de seus ganhos nos dois jogos (cf.
DENZAU, RIKER \& SHEPSLE, 1985; SHEPSLE, 1986).
Essa abordagem é similar à de modelos recentemente de-
senvolvidos por economistas que trabalham na linha de
"expectativas racionais". Nesses modelos um governo dis- 


\section{OS DETERMINANTES DO CONJUNTO DE VITÓRIAS}

É importante entender quais circunstâncias afetam o tamanho do conjunto de vitórias. Três conjuntos de fatores são especialmente importantes:

- as preferências e coalizões do nível II;

- as instituições do nível II e

- as estratégias dos negociadores do nível I.

Consideremos um conjunto de cada vez.

V.1. O tamanho do conjunto de vitórias depende da distribuição de poder, das preferências e das coalizões possíveis entre os grupos domésticos do nível II

Qualquer teoria de negociação internacional de dois níveis que seja testável precisa estar enraizada em uma teoria da política doméstica, ou seja, uma teoria sobre o poder e as preferências dos atores principais do nível II. Este não é o momento para uma avaliação mesmo que superficial das alternativas teóricas relevantes, exceto para mencionar que a estrutura conceitual de dois níveis poderia em princípio aliar-se a diferentes perspectivas, como o marxismo, o pluralismo, os estudos sobre burocracia e o neocorporativismo. Por exemplo, as negociações de armas poderiam ser interpretadas em termos do modelo de burocracias do jogo político do nível II, ao passo que a análise de classes ou o neocorporativismo poderiam ser apro-

cute simultaneamente com outros governos e com sindicatos domésticos sobre política monetária (cf. por exemplo ROGOFF, 1985; VAUBEL, 1986). George Tsebelis (1988) desenvolveu uma teoria de "jogos aninhados" ["nested games"], nos quais duas alianças competem para determinar os ganhos totais, enquanto os jogadores individuais no interior de cada aliança disputam as suas cotas. Fritz Sharpf (1988) interpreta a política macroeconômica como o resultado conjunto de dois jogos simultâneos - em um deles o governo joga contra os sindicatos, enquanto no outro responde às reações antecipadas do eleitorado. James E. Alt e Barry Eichengreen (1987) oferecem uma tipologia mais ampla de jogos interligados, distinguindo os jogos "paralelos" - nos quais "os mesmos oponentes jogam uns contra os outros ao mesmo tempo em mais de uma arena" - e os "jogos sobrepostos" - que surgem "quando um jogador em particular está envolvido ao mesmo tempo em jogos com oponentes distintos e quando a estratégia utilizada em um jogo limita a estratégia disponível em outro". Uma comparação detalhada desses diversos modelos de jogos interligados é uma tarefa para o futuro. priados para analisar a coordenação macroeconômica internacional.

Abstraindo os detalhes da política do nível II, entretanto, é possível esboçar certos princípios que determinam o tamanho dos conjuntos de vitórias. Por exemplo, quanto menor o custo do "não-acordo" para os grupos domésticos, menor será o conjunto de vitórias (HOMER \& ROSENTHAL, 1978). É bom lembrar que o processo de ratificação põe-se, em relação ao acordo proposto, não contra uma variedade de alternativas (possivelmente atraentes), mas apenas contra o "não-acordo"26. O "não-acordo" geralmente representa o status quo, embora em alguns casos o não-acordo possa piorar a situação; essa pode ser uma descrição razoável para o fracasso na ratificação do Tratado de Versalhes ${ }^{27}$.

Alguns grupos domésticos podem ter custos baixos com não-acordos, ao passo que outros podem ter custos mais altos; os primeiros serão mais céticos que os segundos quanto a acordos no nível I. Famílias de baixa renda deveriam ser mais propensas a entrar em greve do que solteiros endinheirados; barbeiros de pequenas cidades deveriam ser mais isolacionistas que banqueiros internacionais. Nesse sentido, alguns grupos domésticos podem tanto opor-se genericamente a quanto apoiar genericamente acordos do nível I, de maneira mais ou menos independente dos conteúdos específicos desses acordos, embora naturalmente as decisões de outros grupos a respeito da ratificação estejam condicionadas a essas particularidades. $\mathrm{O}$ tamanho do conjunto de vitórias (e, daí, o espaço de negociação do negociador do nível I) depende do tamanho relativo das forças "isolacionistas" (que se opõem à cooperação internacional em geral) e das forças "internacionalistas" (que oferecem "apoio incondicional"). O apoio incondicional a acordos internacionais é geralmente maior em países peque-

26 Em tratamentos mais formais, o resultado do não-acordo é chamado de "ponto de reversão". Uma avaliação feita por determinado grupo doméstico sobre o não-acordo corresponde ao que Raiffa chama de "preço da desistência", ou seja, o preço abaixo do qual ele prefere "não negociar" (RAIFFA, 1982). O não-acordo é equivalente ao que Snyder e Diesing chamam de "rompimento" ou o custo esperado da guerra (SNYDER \& DIESING, 1977).

27 A referência do autor, nesse caso, é à recusa do Congresso estadunidense em ratificar o Tratado de Versalhes, que encerrou a I Guerra Mundial e criou a Liga das Nações (N. T.). 
nos, mais dependentes e de economias mais abertas se comparados a países mais autossuficientes, como os Estados Unidos, pois os custos do nãoacordo são em geral mais baixos para seus cidadãos. Coeteris paribus, os estados mais autossuficientes que possuem conjuntos de vitórias menores fazem menos acordos internacionais $\mathrm{e}$ quando os fazem negociam mais duramente.

Em alguns casos, a avaliação do não-acordo pode ser o único desacordo importante entre os grupos do nível II porque seus interesses são relativamente homogêneos. Por exemplo, se a importação de petróleo precisa ser limitada por um acordo entre as nações consumidoras - $\mathrm{o}$ tipo de acordo buscado na Cúpula de Tóquio de 1979, por exemplo -, presume-se que cada grupo doméstico buscará maximizar a sua cota de suprimento disponível em seu país, embora alguns grupos domésticos possam relutar mais que outros em exigir duramente sua parcela por medo de perder integralmente o acordo. Da mesma forma, na maioria das negociações salariais, os interesses dos grupos domésticos (sejam trabalhadores, sejam acionistas) são relativamente homogêneos e as divisões mais significativas entre os grupos do nível II são mais prováveis de acontecer entre "falcões" e "pombos", dependendo de suas disposições de arriscar uma greve. (Walton e McKersie referem-se a isso como conflitos de "fronteira", em que o negociador é pego entre seus grupos domésticos de apoio e a organização externa.) Outros exemplos internacionais em que os interesses domésticos são relativamente homogêneos, com a exceção da avaliação do nãoacordo, podem ser as conversas do SALT $^{28}$, as negociações do Tratado do Canal do Panamá e o conflito árabe-israelense. É improvável que um negociador seja criticado em casa por uma proposta de acordo que reduza as armas do oponente de maneira significativa, ofereça poucas compensações em troca de concessões aos estrangeiros ou que contenha poucas garantias de segurança para o outro lado, embora em cada caso as opiniões possam divergir quanto a arriscar um impasse nas negociações para alcançar esses objetivos.

\footnotetext{
28 Significando "Strategic Arms Limitation Talks" ("Negociações para a Limitação de Armas Estratégicas", em inglês), os acordos SALT foram dois conjuntos de tratativas realizados pelos Estados Unidos e pela União Soviética durante a Guerra Fria, para controle e diminuição das armas nucleares; a primeira rodada de conversas ocorreu entre 1969 e 1972 e a segunda, entre 1977 e 1979 (N. T.).
}

A natureza distinta dessas questões "homogêneas" muda drasticamente ao contrastá-las com os casos em que as preferências dos grupos domésticos são mais heterogêneas e qualquer acordo do nível I atinge desigualmente cada um desses grupos envolvidos. Assim, um programa de recuperação econômica coordenado internacionalmente pode encontrar oposição doméstica tanto por aqueles que acham que o programa está indo longe demais (banqueiros) quanto por aqueles que acham que não está indo suficientemente longe (sindicatos). Em 1919 alguns estadunidenses opuseram-se ao Tratado de Versalhes porque $o$ acharam muito severo para as potências derrotadas e outros porque o acharam muito brando (BAILEY, 1945, p. 16-37). Esses padrões são ainda mais comuns, como logo veremos, quando a negociação envolve diversos temas, como um acordo sobre armas envolvendo barganhas cruzadas entre armas aéreas e navais ou um acordo trabalhista envolvendo salários e pensões. (Walton e McKersie denominam esses conflitos de "facciosos" porque o negociador é posto entre facções em luta dentro da sua própria organização.)

Os problemas encontrados por negociadores do nível I que tratam de conflitos homogêneos (ou "fronteiriços") são bem diferentes daqueles encontrados por negociadores que tratam de conflitos heterogêneos (ou "facciosos"). No primeiro caso, quanto mais o negociador conseguir ganhar no nível I - maior parcela na alocação nacional de petróleo, profundos cortes nos mísseis soviéticos, baixas concessões no Tratado do Canal do Panamá e assim por diante - maiores serão suas chances de conseguir a ratificação. Nesses casos, o negociador pode usar a ameaça implícita de seus próprios falcões para maximizar seus ganhos (ou minimizar suas perdas) no nível I, como Carter e Vance fizeram ao negociar com os panamenhos. Espiando por sobre os ombros para o nível II, o negociador nota que seu problema principal em um conflito de preferências homogêneas é gerenciar as discrepância entre as expectativas de seus grupos de apoio e o resultado negociável. É provável que o negociador não encontre muita simpatia pelas simpatias do inimigo entre seus próprios grupos domésticos, nem muito apoio às posições de seus grupos domésticos no campo inimigo. O efeito da divisão doméstica, incorporada na oposição linha-dura dos falcões, eleva o risco de defecção involuntária e assim impede o acordo no nível I. A crença comum de que a polí- 
tica doméstica é inimiga da cooperação internacional deriva sem dúvida desses casos.

A tarefa de um negociador em meio a um conflito de preferências heterogêneas é mais complicada, embora potencialmente mais interessante. Ao procurar maximizar as chances de ratificação, o negociador não pode simplesmente seguir a regra de "quanto mais, melhor"; a imposição de reparações mais severas à Alemanha em 1919 teria obtido mais alguns votos no nível II mas perdido outros, assim como teria ocorrido com a aceleração do descontrole de preços domésticos do petróleo em 1978. Em alguns casos, essas linhas de divisão entre os grupos domésticos no nível II refletir-se-ão nas do nível I e o negociador do nível I pode encontrar aliados silenciosos no tabuleiro doméstico de seu oponente. Os sindicatos alemães poderiam dar boasvindas à pressão externa sobre seu próprio governo para que este adotasse uma política fiscal mais expansionista e os banqueiros italianos poderiam saudar as demandas internacionais por uma política monetária italiana mais austera. Assim, os alinhamentos transnacionais podem surgir, de maneira tácita ou explícita, quando os interesses domésticos pressionam seus respectivos governos a adotar políticas que sejam mutuamente apoiadas. É claro que é essa a minha interpretação do acordo alcançado na Cúpula da Bonn de 1978.

Em tais casos, a divisão doméstica pode na verdade melhorar as perspectivas para a cooperação internacional. Por exemplo, considerem-se duas diferentes distribuições de preferências dos grupos domésticos entre três alternativas: A, B e não-acordo. Se $45 \%$ dos grupos organizam as preferências assim: $\mathrm{A}>$ não-acordo $>\mathrm{B}$, outros $45 \%$ organizam assim: $B>$ não-acordo $>$ A e $10 \%$ preferem $\mathrm{B}>\mathrm{A}>$ não-acordo, então tanto A quanto $\mathrm{B}$ estão no conjunto de vitórias, mesmo que $\mathrm{B}$ vencesse em um simples jogo no nível II. Por outro lado, se $90 \%$ organizam as alternativas desta forma: $\mathrm{A}>$ não-acordo $>\mathrm{B}$, enquanto $10 \%$ ainda as preferem $\mathrm{B}>\mathrm{A}>$ não-acordo, então apenas A está dentro do conjunto de vitórias. Nesse sentido, um governo que seja internamente dividido tem maiores chances de alcançar um acordo internacional do que um governo firmemente comprometido com apenas uma política ${ }^{29}$. Inversamente, impor instruções vinculantes ex ante aos

29 Raiffa (1982, p. 12) aponta que, "quanto mais difusas forem as posições em cada lado, mais fácil pode ser alcan- negociadores poderia excluir alguns resultados do nível I que, na verdade, seriam potencialmente ratificáveis em ambos os países ${ }^{30}$.

Até o momento supusemos implicitamente que todos os grupos domésticos elegíveis participam do processo de ratificação. Na verdade, contudo, as taxas de participação variam conforme os grupos e as questões e essa variação freqüentemente apresenta implicações para o tamanho do conjunto de vitórias. Por exemplo, quando os custos e/ ou os benefícios de um acordo proposto são relativamente concentrados, é razoável esperar que grupos domésticos cujos interesses são mais afetados buscarão exercer uma influência especial no processo de ratificação ${ }^{31}$. Uma razão pela qual os jogos do nível II são mais importantes para as negociações de comércio do que para questões monetárias é que "o índice de abstenção" dos grupos domésticos é mais alto nas discussões financeiras do que nos debates sobre comércio ${ }^{32}$

A composição de grupos domésticos ativos no nível II (e daí o caráter do conjunto de vitórias) também varia com o nível de politização do assunto. A politização muitas vezes ativa grupos que estão menos preocupados com os custos do nãoacordo, reduzindo assim o tamanho efetivo do conjunto de vitórias. Por exemplo, a politização da questão do Canal do Panamá parece ter reduzido a flexibilidade de negociação de ambos os lados do tabuleiro (HABEEB \& ZARTMAN, 1986). Essa é uma razão por que a maioria dos diplomatas profissionais enfatiza a importância do sigilo

çar-se o acordo externo". Para um contraste para a visão convencional segundo a qual a unidade doméstica é geralmente uma pré-condição do acordo internacional, cf. Artis e Ostry (1986, p. 75-76).

30 "Consultas significativas com outras nações tornam-se muito difíceis quando o processo interno de tomada de decisão já tem algumas das características de pacto entre entidades quase-soberanas. Existe uma crescente relutância de pôr em risco um consenso doméstico alcançado penosamente em um fórum internacional" (KISSINGER, 1969, p. 266).

31 Cf. Wilson (1975) sobre como as políticas de determinada questão são afetadas pela concentração ou difusão dos custos e dos benefícios.

32 Outro fator que favorece a abstenção são as maiores complexidade e opacidade das questões monetárias; como Gilbert R. Winham (1977, p. 363) observa, "a complexidade pode fortalecer a posição de um negociador vis-à-vis a organização que ele representa”. 
para negociações exitosas. Entrementes, a viagem transcontinental de Woodrow Wilson em 1919 refletiu o cálculo oposto, a saber, que expandindo o número de apoiadores internos ele poderia assegurar a ratificação do Tratado de Versalhes, embora no fim esta estratégia tenha-se mostrado infrutífera (BAILEY, 1945).

Uma outra importante restrição à nossa discussão até o momento foi o pressuposto de que as negociações envolvem somente um tema. Suavizar esse pressuposto tem conseqüências poderosas para a disputa em ambos os níveis ${ }^{33}$. Diversos grupos do nível II provavelmente terão preferências bem diferentes sobre as questões debatidas em uma negociação envolvendo diversos temas. Como regra geral, o grupo com maior interesse em determinada questão provavelmente terá a posição mais extremada quando ela for debatida. Nas negociações sobre a Lei do Mar, por exemplo, o Departamento de Defesa tinha forte interesse nas rotas marítimas, o Departamento do Interior em direitos de mineração no leito marinho e assim por diante (HOLLICK, 1981, especialmente p. 208-237; SEBENIUS, 1984, especialmente p. 74-78). Se cada grupo consegue imprimir sua visão e interesse no acordo do nível I, o pacote resultante muito provavelmente seria inegociável, ou seja, não ratificável pelos países oponentes (RAIFFA, 1982, p. 175).

Assim, o negociador-chefe enfrenta barganhas cruzadas em diferentes temas: quanto ceder em direitos de mineração para conseguir proteção em rotas marítimas, quanto ceder em exportação de cítricos para conseguir um acordo melhor na exportação de carnes e assim por diante. As implicações dessas barganhas cruzadas para os respectivos conjuntos de vitórias podem ser analisadas por meio de curvas "isovotos" ou curvas de "indiferença política". Essa técnica é análoga à análise convencional de curvas de indiferença, exceto pelo fato de que a medida operacional é a perda de votos e não a perda de utilidade. A Figura 2 apresenta um diagrama de análise de Edgeworth $^{34}$. O resultado mais desejado para A

\footnotetext{
33 Sou grato a Ernst B. Haas e Robert O. Keohane pelo útil aconselhamento sobre esse ponto.

34 Estou em débito com Lisa Martin e Kenneth Shepsle por sugerirem essa abordagem, embora eles não sejam responsáveis pela minha aplicação. Note-se que essa construção presume que cada questão, considerada individualmen-
}

(o resultado que obtém aprovação unânime tanto da indústria de laranjas como da indústria de carnes) é o canto superior direito $\left(\mathrm{A}_{\mathrm{M}}\right)$ e cada curva côncava em relação ao ponto $\mathrm{A}_{\mathrm{M}}$ representa $\mathrm{o}$ lócus de todas as possíveis barganhas cruzadas entre os interesses de pecuaristas e citricultores, de tal forma que o voto líquido alcançado em favor da ratificação nos pontos $\mathrm{A}$ do nível II seja constante. A linha negritada $\mathrm{A}_{1}-\mathrm{A}_{2}$ representa a votação mínima necessária para ratificação por $\mathrm{A}$; a área definida à direita de $\mathrm{A}_{1}-\mathrm{A}_{2}$ representa o conjunto de vitórias de $\mathrm{A}$. Da mesma forma, a linha $\mathrm{B}_{1}-\mathrm{B}_{2}$ representa os resultados que são minimamente ratificáveis por $\mathrm{B}$ e a área em forma de lente entre $A_{1}-A_{2}$ e $B_{1}-B_{2}$ representa o conjunto de acordos viáveis. Embora algumas sutilezas adicionais (como a natureza da "curva de contrato") possam ser obtidas desse tipo de análise, o ponto central é simples: as chances de alcançar-se conjuntos de acordos abrem um rico leque de alternativas estratégicas para os negociadores em jogos de dois níveis.

\section{FIGURA 2 - CURVAS DE INDIFERENÇA POLÍTICA PARANEGOCIAÇÃO DE DOIS TEMAS}

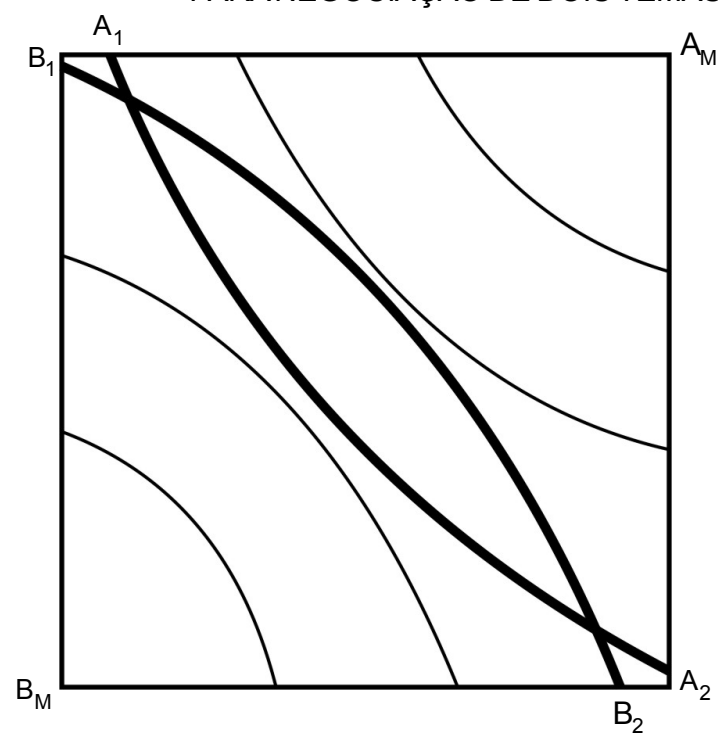

Um tipo de vínculo entre questões [issue linkage] é absolutamente crucial para compreender como as políticas doméstica e internacional tornam-se entrelaçadas ${ }^{35}$. Suponha-se que u'a

te, é do tipo "homogêneo" e não do tipo "heterogêneo". A elaboração de curvas de indiferença política de votos ("isovotos") para questões de tipo heterogêneo é mais complicada.

35 Sou grato a Henry Brady por esclarecer esse ponto para mim. 
maioria de grupos domésticos no nível II opõe-se a determinada política (digamos, a desregulamentação do preço do petróleo), porém alguns membros dessa maioria estariam inclinados a mudar seus votos em troca de mais empregos (digamos, nas indústrias exportadoras). Se a barganha é limitada ao nível II, essa troca não é tecnicamente viável, mas se o negociador-chefe conseguir fechar um acordo internacional que traga mais empregos (digamos, via maior crescimento no exterior), ele pode com efeito subverter o resultado inicial do tabuleiro doméstico. Esse vínculo entre questões transnacionais foi um elemento crucial no acordo de Bonn em 1978.

Note-se que essa estratégia funciona por meio da mudança das preferências de quaisquer grupos domésticos, mas sim da criação de uma opção política (como um crescimento maior nas exportações) que estava anteriormente além do controle doméstico. Por esse motivo denomino esse tipo de vínculo entre questões do nível I que altera os resultados possíveis no nível II de conexão sinérgica. Por exemplo, "na Rodada de Tóquio [...] os países usaram a negociação internacional para promover reformas internas em situações nas quais as pressões dos grupos domésticos de outra forma impediriam a ação, caso não houvesse a pressão (e os benefícios das barganhas) que um parceiro estrangeiro poderia fornecer" (WINHAM, 1987). A interdependência econômica multiplica as oportunidades de alteraremse as coalizões domésticas (e, daí, os resultados das políticas) ao expandir o conjunto de alternativas viáveis - com efeito, ao criar entrelaçamentos políticos para além das fronteiras nacionais. Assim, deveríamos esperar que a conexão sinérgica (que é, por definição, explicável apenas em termos da análise de jogos de dois níveis) torne-se mais freqüente à medida que a interdependência cresce.

\section{V.2. O tamanho do conjunto de vitórias depende das instituições políticas do nível II}

Os procedimentos de ratificação claramente afetam o tamanho do conjunto de vitórias. Por exemplo, se dois terços dos votos são necessários para a ratificação, o conjunto de vitórias quase com certeza será menor do que no caso de uma simples maioria ser necessária. Como um observador experiente notou, "Sob as regras da Constituição, trinta e quatro de 100 senadores podem bloquear a ratificação de qualquer tratado. Esse é um aspecto infeliz e único de nossa democracia. Devido ao poder efetivo de veto de um pequeno grupo, muitos acordos valiosos foram rejeitados e muitos não são nem sequer considerados para ratificação" (CARTER, 1982, p. 225). Como assinalado anteriormente, a separação de poderes nos Estados Unidos impõe uma restrição mais rígida sobre o conjunto de vitórias estadunidense do que em vários outros países. Isso aumenta o poder de barganha de negociadores norte-americanos, mas também reduz o escopo da cooperação internacional. Tal situação eleva as probabilidades de defecção involuntária e torna os sócios potenciais mais cautelosos ao negociar com os estadunidenses.

A Lei de Expansão do Comércio de 1974 modificou os procedimentos de ratificação em um esforço para reduzir a possibilidade de manipulação do acordo final pelo Congresso e com isso buscou renovar a confiança dos parceiros dos Estados Unidos nas negociações internacionais. Após o fiasco do Preço de Venda Americano, tornou-se amplamente reconhecido que a ratificação fragmentada de qualquer novo acordo pelo Congresso inibiria negociações internacionais. Por isso, a Lei de 1974 garantiu uma votação única para rejeitar ou aceitar os acordos no Congresso. Entretanto, para satisfazer as sensibilidades do poder Legislativo estabeleceu-se um elaborado sistema de comitês do setor privado para melhorar a comunicação entre os negociadores do nível I e seus grupos domésticos do nível II, o que era na verdade uma forma de cooptar os grupos de interesse ao expô-los diretamente às implicações de suas demandas (WINHAM, 1980; TWIGGS, 1987). Precisamente essa tática é descrita em um estudo de caso sobre a administração do trabalho realizado por Walton e McKersey: "Em vez de assumir a responsabilidade por persuadir diretamente os principais grupos domésticos a reduzir suas expectativas, [o negociador do nível I] estrutura uma situação de tal forma que esses grupos (ou seus representantes mais imediatos) persuadir-se-ão sozinhos" (WALTON \& MCKERSIE, 1965, p. 321).

Nem todas as práticas importantes de ratificação estão formalizadas; por exemplo, a propensão japonesa de buscar o consenso doméstico mais amplo possível antes de agir restringe o conjunto de vitórias japonês, em contraste com a cultura política de sociedades majoritárias. Outras práticas políticas domésticas também podem afetar o 
tamanho do conjunto de vitórias. Uma forte disciplina no partido do governo, por exemplo, aumenta o conjunto de vitórias ao ampliar o alcance dos acordos pelos quais o negociador do nível I pode esperar apoio. Por exemplo, em 1986, no comitê misto Câmara-Senado da reforma tributária, a proposta final estava muito próxima da versão do Senado, a despeito do (ou melhor, devido ao) grande controle do Congressista Rostenkowski sobre a sua delegação, que aumentou o conjunto de vitórias da Câmara. Ao contrário, um enfraquecimento da disciplina partidária nas maiores nações ocidentais, coteris paribus, reduziria o escopo para a cooperação internacional.

A recente discussão sobre "força do Estado" e "autonomia do Estado" é relevante aqui. Quanto maior for a autonomia dos tomadores centrais de decisões em relação aos grupos domésticos do nível II, maior será seu conjunto de vitórias e, assim, maiores serão as chances de alcançar-se um acordo internacional. Por exemplo, o insulamento do Banco Central das pressões políticas domésticas de fato aumenta o conjunto de vitórias e, portanto, as chances de cooperação monetária internacional; as recentes propostas para um papel mais relevante para os bancos centrais na coordenação de políticas baseiam-se nesse ponto (ARTIS \& OSTRY, 1986) ${ }^{36}$. Entretanto, a análise de dois níveis também implica que, coteris paribus, quanto mais forte for a autonomia de um Estado em relação às pressões domésticas, mais fraca é sua posição relativa ao barganhar internacionalmente. Por exemplo, os diplomatas que representam uma ditadura fortificada são menos capazes que representantes de uma democracia de argumentar que os grupos domésticos impedem a realização de um acordo desvantajoso (SCHELLING, 1960, p. 28). Essa ainda é outra faceta da desconcertante ambigüidade da noção de "força do Estado".

Para simplicidade de exposição, meu argumento é redigido em termos de apenas dois níveis. Contudo, muitos arranjos institucionais requerem diversos níveis de ratificação, multiplicando assim a complexidade (mas talvez também a importância) da análise baseada em conjuntos de vitórias. Considere-se, por exemplo, as negociações entre os Estados Unidos e a Comunidade Euro-

\footnotetext{
36 É óbvio que se isso é desejável em termos democráticos é uma questão bastante diferente.
}

péia sobre o comércio agrícola. De acordo com o Tratado de Roma, modificações na Política Agrícola Comum requerem ratificação unânime pelo Conselho de Ministros ${ }^{37}$, o qual representa cada um dos estados-membro. Ato contínuo, cada um desses governos precisa ratificar suas decisões na arena nacional e em governos de coalizão esse processo pode requerer também ratificação no interior de cada partido. Da mesma forma, uma ratificação desse tipo no lado estadunidense precisaria (ao menos informalmente) do apoio da maioria das, se não de todas as, grandes organizações agrícolas e no interior dessas organizações outras ratificações pelos interesses e regiões-chave podem ser necessárias. Em cada estágio precisariam ser considerados os padrões de divisão política interna, os vínculos entre questões, as compensações paralelas [side-payments], as estratégias do negociador e assim por diante. Em algum ponto dessa regressão analítica a complexidade de mais decomposições excederia as vantagens da simplificação, mas o exemplo ilustra a necessidade da meditação cuidadosa sobre a lógica dos jogos de múltiplos níveis.

\section{3. O tamanho do conjunto de vitórias depende das estratégias dos negociadores do nível I}

Cada negociador do nível I tem um interesse inequívoco de maximizar o conjunto de vitórias do outro negociador, mas em relação ao seu próprio conjunto de vitórias suas motivações são variadas. Quanto maior for seu conjunto de vitórias, mais facilmente ele conclui um acordo, mas também mais fraca é sua posição de barganha vis-àvis o outro negociador. Esse aspecto freqüentemente apresenta um dilema tático. Uma forma eficiente de demonstrar comprometimento com determinada posição nas negociações do nível I é arregimentar o apoio dos grupos domésti-

\footnotetext{
37 O Tratado de Roma foi um acordo celebrado em 1957 entre Alemanha, França, Itália, Bélgica, Países Baixos e Luxemburgo, criando a Comunidade Econômica Européia. A Política Agrícola Comum é um conjunto de subsídios fornecido pela Comunidade Européia aos agricultores dos seus países-membro. O Conselho de Ministros é um órgão da Comunidade Européia que, precisamente, reúne os representantes de cada um dos estados-membro. Por fim, cabe lembrar que a Comunidade Européia foi criada em 1957 com esse nome e que, em 1992, transformou-se em União Européia (N. T.).
} 
cos a essa posição (por exemplo: mantendo um indicativo de greve, falando em "missile gap"38 ou denunciando as "práticas injustas de comércio" no exterior). Por outro lado, essas táticas podem ter efeitos irreversíveis sobre as atitudes dos grupos domésticos, dificultando a ratificação subseqüente de um acordo fechado (WALTON \& MCKERSIE, 1965, p. 345). Inversamente, se o negociador realizar consultas preliminares junto a grupos domésticos com o objetivo de "amaciálos" antes da luta pela ratificação, sua imagem de negociador implacável no exterior pode ficar comprometida.

Contudo, desconsiderando neste momento esses dilemas e assumindo que um negociador deseja expandir o seu conjunto de vitórias a fim de encorajar a ratificação de um acordo, ele pode explorar tanto as compensações paralelas convencionais como uma genérica "boa vontade". O uso das compensações paralelas para atrair apoiadores marginais, sem dúvida, é bastante comum na teoria dos jogos, assim como na política real. Por exemplo, o governo Carter fez diversas ofertas persuasivas (como projetos de obras públicas) com o objetivo de convencer senadores hesitantes a ratificar o Tratado do Panamá (CARTER, 1982, p. 172; cf. também RAIFFA, 1982, p. 183). Em um jogo de dois níveis as compensações paralelas podem vir de fontes domésticas sem nenhuma relação com o tema, como nesse caso, ou podem-se receber como parte da negociação internacional.

O papel das compensações paralelas nas negociações internacionais é bem conhecido. Todavia, a abordagem de dois níveis enfatiza que o valor de uma compensação paralela internacional deve ser calculado em termos da sua contribuição marginal para a probabilidade de ratificação e não em termos do seu valor total para a nação beneficiada. O que importa no nível II não são os custos e benefícios nacionais totais, mas sim os seus impactos, relativamente às coalizões existentes $e$ às protocoalizões. Uma concessão comercial que envolva todos os participantes (ou, ainda pior, uma concessão em um produto de interesse de um

38 O "missile gap" ("hiato de mísseis", em inglês) foi um recurso retórico usado nos Estados Unidos durante a Guerra Fria que exagerava a diferença do estoque de mísseis nucleares estadunidenses em relação à União Soviética, a fim de justificar maiores gastos com esse tipo de armamento (N. T.). congressista comprometido com o livre comércio) é menos efetiva que uma concessão (mesmo que seja de menor valor intrínseco) capaz de alterar a posição de um eleitor indeciso. Inversamente, a retaliação comercial não deveria direcionarse nem aos partidários do livre comércio nem aos protecionistas convictos, mas sim aos não comprometidos.

Um negociador experiente, familiarizado com os respectivos tabuleiros domésticos, deveria ser capaz de maximizar tanto a relação custo-benefício (para si e para seus grupos domésticos) das concessões que deve fazer para assegurar uma ratificação no exterior como a relação custo-benefício de suas próprias demandas e ameaças, ao mirar suas iniciativas com um olho sobre seus efeitos no nível II, tanto em casa como no exterior. Nessa empreitada, os negociadores do nível I estão freqüentemente em conluio, pois cada um tem interesse em ajudar o outro a conseguir que o acordo final seja ratificado. Com efeito, eles movimentam-se coordenadamente na busca de pontos de tangência de suas respectivas curvas políticas de indiferença. A freqüência empírica dessa estratégia em negociações de comércio e guerras comerciais, assim como em outras negociações internacionais, seria um teste crucial dos méritos relativos do modelo convencional de ator unitário em contraposição à abordagem de dois níveis proposta aqui ${ }^{39}$.

Além do uso de compensações paralelas específicas, um negociador-chefe cuja reputação política doméstica seja alta pode conseguir mais facilmente a ratificação de suas iniciativas externas.

39 O significado estratégico de observar os efeitos das ações do negociador em ambos os níveis II é ilustrado por John Conybeare (1985, p. 157): a retaliação nas guerras comerciais anglo-hanseáticas não surtia o desejado efeito de acabar com o conflito porque não tinha como alvo (e talvez nem pudesse ter tido) membros cruciais da coalizão oposta do nível II. Compare-se isso com Snyder e Diesing (1977, p. 552): "Se alguém enfrenta um oponente com força para impor sua vontade, mas a coalizão majoritária do oponente inclui alguns membros hesitantes inclinados à conciliação, uma proposta de compromisso que se ajuste aos seus pontos de vista pode provocar sua defecção e a formação de uma nova coalizão majoritária. Ou se a estratégia do oponente é de acomodação, baseada em uma tênue coalizão de programaticamente débil, sabe-se que é necessário tomar cuidado na implementação da sua própria estratégia coercitiva para evitar o tipo oposto de guinada na outra situação". 
Embora a boa vontade genérica não possa garantir a ratificação, como Woodrow Wilson acabou descobrindo, ela é útil para expandir o conjunto de vitórias, favorecendo assim o acordo no nível I, pois ela constitui uma espécie de "cola-tudo" para a sua coalizão de apoio. Walton e McKersie mencionam que membros do Sindicato dos Trabalhadores da Indústria Automobilística, ao falarem de seu reverenciado líder, Walter Reuther, argumentaram: "Eu não entendo ou concordo com esta idéia de divisão de lucros, mas se o Ruivo deseja-a, eu vou junto" (WALTON \& MCKERSEY, 1965, p. 319). O negociador iugoslavo na disputa de Trieste atenuou posteriormente suas dificuldades em convencer os eslovenos irredentistas a aceitarem um acordo, afirmando que "o governo [i.e., Tito] pode influenciar a opinião pública sempre que desejar" (Velebit apud CAMPBELL, 1976, p. 97) ${ }^{40}$.

Note-se que cada negociador do nível I tem forte interesse na popularidade do seu oponente, pois a popularidade do partido A aumenta o tamanho do seu conjunto de vitórias e, portanto, aumenta tanto as chances de sucesso e de influência relativa da barganha do partido B. Dessa forma, os negociadores devem normalmente tentar reforçar a posição uns dos outros com seus respectivos grupos domésticos.

Em parte por essa razão e em parte devido à atenção dos meios de comunicação, a participação na cena mundial normalmente dá ao chefe de governo uma vantagem especial vis-à-vis sua oposição doméstica. Desse modo, embora a coordenação política internacional sofra com os altos custos de transação, os chefes de governo também conseguem colher aquilo que denominamos de "benefícios de transação". De fato, o recente aumento do número de cúpulas ocidentais, que deram mais ênfase à publicidade do que à substância, parece ser desenhado para aproveitar esses "benefícios de transação", sem na verdade lidar com certos tipos de acordos que poderiam acarretar custos de transação ${ }^{41}$.

\footnotetext{
40 Conforme indicado anteriormente, nossa discussão assume que o negociador do nível I deseja alcançar um acordo ratificável. Em casos (que mencionaremos adiante) em que as preferências pessoais do negociador são mais linha-dura do que as preferências de suas bases, a sua popularidade doméstica poderia permitir-lhe resistir a acordos do nível I.

41 Os benefícios de transação podem ser incrementados se um acordo substantivo é alcançado, embora algumas vezes
}

Negociadores de status mais elevado têm maior probabilidade de dispor de mais compensações paralelas e mais "boa vontade" em casa e, por isso, os estrangeiros preferem negociar com um chefe de governo a tratar com um servidor mais baixo. Em termos puramente distributivos, uma nação poderia ter vantagem de barganha se seu negociador-chefe fosse um mero funcionário. Os diplomatas agem racionalmente e não apenas simbolicamente quando se recusam a negociar com um interlocutor de posição inferior. Os parceiros de negociação dos estadunidenses têm razão em preocupar-se sempre que o Presidente dos Estados Unidos está enfraquecido domesticamente.

\section{INCERTEZAE TÉCNICAS DE BARGANHA}

Os negociadores do nível I são freqüentemente mal-informados a respeito da política do nível II, particularmente sobre o lado da oposição. Em 1978, os negociadores em Bonn estavam geralmente equivocados sobre a política local dos demais países; por exemplo: a maioria dos funcionários estadunidenses não apreciou o complexo jogo doméstico que o Chanceler Schmidt praticou sobre o tema da recuperação alemã. Igualmente, Snyder e Diesing informam que "os tomadores de decisão em nossos casos apenas ocasionalmente tentam fazer essas avaliações e quando tentaram fizeram-no miseravelmente [...]. Geralmente os governos não analisam bem a política interna dos demais países durante as crises [e eu adicionaria: também em ocasiões normais]; na verdade, fazer essa análise é inerentemente difícil" (SNYDER \& DIESING, 1977, p. 516, 522-523) ${ }^{42}$. Atenuar o pressuposto da informação perfeita com o intuito de permitir a existência da incerteza tem diversas implicações para a nossa compreensão dos jogos de dois níveis. Deixem-me esclarecer algumas dessas implicações.

A incerteza sobre o tamanho do conjunto de vitória pode ser tanto um instrumento de barganha quanto um obstáculo para negociações de dois níveis. Em barganhas de nível I puramente distributivas, os negociadores têm um incentivo para expor de maneira moderada seus conjuntos de vitórias. Como é provável que cada negociador conheça mais seu próprio nível II que seu oponente, essa afirmação tem alguma

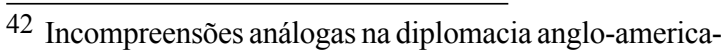
na são o foco de Neustadt (1970).
} 
plausibilidade. Isso tem a ver com uma tática que Snyder e Diesing descrevem quando negociadores buscam explorar divisões no interior do seu próprio governo ao dizerem, de fato: "É melhor vocês fazerem um acordo comigo porque a alternativa é ainda pior" (idem, p. 517).

Por outro lado, a incerteza sobre o conjunto de vitórias do oponente aumenta a preocupação do negociador com o risco de defecção involuntária. Os acordos somente podem ser fechados se cada negociador estiver convencido de que o acordo proposto está dentro do conjunto de vitórias do oponente e que, portanto, será ratificado. A incerteza sobre a ratificação do acordo pelo partido A diminui o valor esperado do acordo para o partido B e por isso o partido B solicitará ao partido A uma compensação paralela mais generosa do que seria necessário sob condições de certeza. De fato, o partido B tem um incentivo para fingir que duvida da capacidade de o partido A cumprir o acordo, precisamente para extrair uma oferta mais generosa ${ }^{43}$.

Por isso, um negociador maximizador de utilidade precisa convencer seu oponente de que seu próprio conjunto de vitórias é “incomum” [kinky], ou seja, que o acordo proposto será ratificado com certeza, mas que um acordo um pouco mais favorável ao oponente é improvável que seja ratificado. Por exemplo, nas discussões sobre energia em 1978, ao enviar o Senador Byrd em uma missão pessoal a Bonn antes da cúpula e, assim, ao discutir seus problemas políticos em um longo tetê-à-tête com o Chanceler, Carter procurou com sucesso convencer Schmidt que a desregulamentação imediata era politicamente impossível, mas que por volta de 1981 seria politicamente factível. Os conjuntos de vitórias incomuns podem ser mais críveis se girarem em torno daquilo que Schelling chama de solução "proeminente", como uma divisão meio a meio dos ganhos, pois tais resultados poder vendáveis mais claramente em casa. Outra tática relevante consiste em o negociador apresentar um acordo experimental para ratificação com o objetivo de demonstrar que esse acordo não está dentro do seu conjunto de vitórias.

A incerteza sobre os contornos das respectivas "curvas de indiferença política", portanto, tem

43 Sou grato a Robert O. Keohane por indicar o impacto da incerteza sobre o valor esperado das propostas. usos estratégicos. Por outro lado, quando os negociadores estão buscando novos pacotes que possam melhorar as posições de ambos os lados, a descrição enganosa do conjunto de vitórias de alguém pode ser contraproducente. As soluções criativas que expandem o escopo dos ganhos conjuntos e melhoram as chances de ratificação do acordo provavelmente requererão informações muito acuradas sobre as preferências e sobre os pontos sensíveis dos grupos domésticos. A análise de jogos de dois níveis esclarece bem a observação de Zartman segundo a qual toda negociação envolve "a troca controlada de informações parciais” (ZARTMAN, 1976, p. 14) 44

\section{REESTRUTURAÇÃO E REVERBERAÇÃO}

Em termos formais, a teoria dos jogos exige que a estrutura das questões e dos resultados [payoffs] seja explicitada previamente. Entretanto, na verdade muito do que acontece em qualquer situação de barganha envolve tentativas dos jogadores de reestruturar o jogo e alterar as percepções dos demais a respeito dos custos do nãoacordo e dos benefícios dos acordos propostos. Essas táticas são mais difíceis de terem sucesso em jogos de dois níveis do que em negociações convencionais, pois é mais difícil atingir os grupos domésticos do outro lado com mensagens convincentes. Contudo, os governos realmente procuram expandir os conjuntos de vitórias uns dos outros. Muito da atividade diplomática - persuadir formadores de opinião, estabelecer contatos com partidos de oposição, oferecer ajuda humanitária a um governo amigo mas instável e assim por diante - tem exatamente essa função. Quando funcionários japoneses visitam o Congresso dos Estados Unidos ou diplomatas britânicos tentam influenciar os líderes irlando-americanos, eles buscam enfraquecer eventuais restrições do-

\footnotetext{
44 A presente análise pressupõe que os grupos domésticos são míopes sobre o nível II do outro lado, um pressuposto que não é empiricamente irrealista. Entretanto, um grupo doméstico plenamente informado levaria em consideração as preferências de jogadores-chave do outro lado, pois, se a proposta em questão enquadra-se bem no conjunto de vitórias do outro lado, seria racional para esse grupo votar contra ela, esperando uma proposta mais favorável em uma segunda rodada e ainda assim ratificável no exterior. Essa poderia ser uma interpretação razoável para a posição do Senador Lodge em 1919 (BAILEY, 1945). Considerar esse uso estratégico da votação no nível II está além do escopo deste artigo.
} 
mésticas que de outra maneira evitariam a cooperação do governo local com seus próprios governos.

Outro exemplo esclarecedor de ações de um negociador que busca aumentar as chances de ratificação frente à oposição no nível II ocorreu em 1977 durante as negociações entre o Fundo Monetário Internacional (FMI) e o governo italiano. As demandas iniciais do FMI por austeridade dispararam uma forte oposição dos sindicatos e dos partidos de esquerda. Embora a posição de barganha do FMI no nível I parecesse forte, o negociador do Fundo buscou um consenso mais amplo em torno de um acordo entre os diversos atores italianos como forma de prevenir a defecção involuntária. Assim, após consultas diretas com os líderes sindicais e de esquerda, o FMI reestruturou a sua proposta com foco em investimentos de longo prazo e na recuperação econômica (por acaso, um interessante exemplo de objetivo bem delimitado) sem se afastar de suas demandas de curto prazo. Ironicamente, o apoio inicial dos comunistas à revisão do acordo não durou devido a conflitos entre facções moderadas e doutrinárias do Partido Comunista Italiano, o que mostra a importância da análise em vários níveis (HILLMAN, 1980) ${ }^{45}$.

Em algumas situações, talvez mesmo sem intenção, as pressões internacionais "reverberam" na política doméstica, alterando o equilíbrio doméstico e, em conseqüência, influenciando as negociações internacionais. Exatamente esse tipo de reverberação caracterizou as negociações da Cúpula de 1978. Dieter Hiss, o xerpa alemão e um dos que acreditava em um programa de estímulo econômico como algo interessante para a Alemanha, mais tarde escreveu que as cúpulas mudam a política nacional " [...] apenas e tão-somente se forem capazes de mobilizar e/ou mudar a opinião pública e a atitude dos grupos políticos [...]. Freqüentemente isso é suficiente se o equilíbrio de opiniões for alterado, produzindo uma apertada maioria que anteriormente era uma forte minoria obstaculizadora do processo [...]. Nenhum país viola seus próprios interesses, mas certamente as

\footnotetext{
45 Spaventa (1983) argumenta que os sindicatos e os comunistas na verdade apoiaram as medidas de austeridade, mas acharam as exigências do FMI úteis para negociar com suas próprias bases.
}

definições de seus interesses podem mudar ao longo de uma cúpula com suas possíveis barganhas e toma-lá-dá-cá” (HISS, 1980, p. 286-287).

Do ponto de vista da teoria ortodoxa da escolha racional, a reverberação é problemática porque implica certa interconexão entre as funções de utilidade dos atores independentes, ainda que por meio dos diferentes níveis do jogo. Duas rationales podem ser apresentadas para explicar a reverberação entre atores egoístas e maximizadores da utilidade. Primeiro, em um mundo complexo e interdependente mas freqüentemente hostil, ofender estrangeiros pode ser custoso no longo prazo. "Para progredir, vá com demais" ["to get along, go along"] pode ser u'a máxima racional. É provável que, quanto mais dependente (ou interdependente) for uma nação, mais comum será essa rationale, assim como mais persuasiva em relação aos atores do nível II mais expostos internacionalmente, como as corporações multinacionais e os bancos internacionais.

Uma segunda rationale leva em conta os fatores cognitivos e a incerteza. Seria um erro para cientistas políticos imitar muitos economistas e desconsiderar o elemento persuasivo das negociações $^{46}$. Dada a incerteza difundida que permeia muitas questões internacionais, as mensagens do exterior podem mudar as idéias, mover os indecisos e encorajar a minoria doméstica. Como um negociador alemão explicou sua conversão retardatária para a causa da "locomotiva" em 1978, "No final, até mesmo o Banco de Compensações Internacionais [a cautelosa organização de bancos centrais da Basiléia] apoiou a idéia de coordenação das ações entre os países". Da mesma forma, um defensor entusiástico do programa saudou a pressão internacional por ter propiciado um empurrão útil para a política doméstica alemã.

É mais provável que uma reverberação persuasiva ocorra mais entre países com relações próximas e que aconteça com mais freqüência em negociações econômicas do que em tratativas político-militares. Os comunicados das cúpulas ocidentais são freqüentemente mencionados pe-

\footnotetext{
46 Sobre explicações cognitivas e de comunicação para a cooperação internacional, cf., por exemplo, Zartman (1976, especialmente a parte 4), Haas (1980, p. 357-405) e Cooper (1986).
} 
los participantes para suas audiências domésticas como uma forma de legitimar suas políticas. Após uma declaração desse tipo feita pelo Chanceler Schmidt, um de seus auxiliares caracterizou privadamente o argumento como "inválido intelectual, porém útil politicamente". Por outro lado, é bastante conhecido pelos participantes de cúpulas que uma declaração contrária à política vigente de determinado governo poderia ser usada de maneira lucrativa pelos seus oponentes. Algumas propostas recentes do Congresso dos Estados Unidos que tinham como objetivo assegurar uma publicidade doméstica maior para comentários internacionais sobre políticas econômicas nacionais (incluindo as recomendações até então confidenciais do FMI) acabaram por difundir a idéia segundo a qual a reverberação poderia aumentar a cooperação internacional (HENNING, 1987, p. 62-63).

A reverberação, conforme discutida até o momento, implica que a pressão internacional expande o conjunto de vitórias doméstico e facilita o acordo. Entretanto, a reverberação também pode ser negativa, no sentido de que a pressão externa pode ocasionar uma reação doméstica adversa. A reverberação negativa provavelmente é menos comum empiricamente do que a reverberação positiva, simplesmente porque os estrangeiros são propensos a desistirem da pressão pública se esta for reconhecidamente contraprodutiva. A teoria do equilíbrio cognitivo sugere que a pressão internacional é mais propensa a reverberar negativamente se geralmente sua fonte for vista pelas audiências domésticas como uma adversária em vez de uma aliada. Todavia, prever o efeito exato da pressão externa é reconhecidamente difícil, embora empiricamente a reverberação pareça ocorrer com freqüência em jogos de dois níveis.

O fenômeno da reverberação (juntamente com a conexão sinérgica de questões, descrita anteriormente) previne o uso de um atalho atraente para a modelagem de jogos de dois níveis. Se as preferências nacionais fossem exógenas do ponto de vista das relações internacionais, o jogo político doméstico poderia ser modelado separadamente e os "produtos" desse jogo poderiam ser usados como "demandas" no jogo internacional" 47 A divisão do trabalho entre a política comparada e as

47 Essa é a abordagem utilizada para analisar as negociações anglo-chinesas sobre Hong Kong em Bueno de Mesquita, Newman e Rabushka (1985). relações internacionais poderia continuar a existir, embora alguns observadores curiosos talvez desejassem continuar acompanhando o jogo em ambos os tabuleiros. Mas se as pressões internacionais reverberam na política doméstica, ou se as questões podem ser interconectadas sinergicamente, os resultados domésticos não são exógenos e os dois níveis não podem ser modelados independentemente.

\section{O PAPEL DO NEGOCIADOR-CHEFE}

No modelo estilizado de jogos de dois níveis delineado aqui, o negociador-chefe é a única conexão formal entre o nível I e o nível II. Até o momento assumi que o negociador-chefe não tem perspectivas políticas independentes, mas que age meramente como um honesto intermediário, ou melhor, como um representante dos interesses dos grupos domésticos. Essa suposição simplifica poderosamente a análise de jogos dois níveis. Entretanto, a teoria agente-principal lembra-nos de que essa suposição não é realista ${ }^{48}$. Empiricamente, as preferências do negociadorchefe podem muito bem divergir das dos grupos domésticos. As negociações de dois níveis são custosas e arriscadas para o negociador-chefe e freqüentemente interferem em suas demais prioridades; portanto, é razoável perguntar o que motiva esse negociador a participar de negociações de dois níveis.

As motivações do negociador-chefe incluem:

1. fortalecer sua posição no jogo do nível II por meio do aumento de seus recursos políticos ou por meio da minimização das perdas potenciais. Por exemplo, um chefe de governo pode alcançar a popularidade que almeja para si caso conclua com sucesso um acordo internacional, ou ele pode antecipar que os resultados do acordo (por exemplo, crescimento mais rápido ou gastos mais baixos em defesa) serão politicamente recompensadores;

\footnotetext{
48 Para uma visão geral dessa literatura, cf. Moe (1984), Pratt e Zeckhauser (1985) e Mitnick (1986). Essa literatura é apenas indiretamente relevante em relação ao nosso interesse neste trabalho, pois ela não aborda adequadamente o problema gerado por mandantes [principals] múltiplos (ou, em nossos termos: grupos domésticos de apoio). Para uma abordagem altamente formal do problema de mandantes múltiplos, cf. Bernheim e Whinston (1986).
} 
2. mudar o equilíbrio de poder no nível II em favor de políticas domésticas que prefere por motivos exógenos. As negociações internacionais às vezes permitem aos líderes políticos fazerem aquilo que domesticamente eles não têm poder suficiente para fazê-lo. Além do agora conhecido caso de 1978, esse padrão caracteriza muitos programas de estabilização que são (enganosamente) "impostos" pelo FMI. Por exemplo, nas negociações de 1974 e de 1978 entre a Itália e o FMI, as forças conservadoras internas usaram a pressão do FMI para facilitar mudanças de políticas que de outra maneira não seriam viáveis internamente (SPAVENTA, 1983; HILLMAN, 1986) e

3. perseguir sua própria concepção do interesse nacional no contexto internacional. Isso parece ser a melhor explicação para o prodigioso esforço de Jimmy Carter em favor do Tratado do Canal do Panamá, assim como para o compromisso em última análise fatal de Woodrow Wilson com o Tratado de Versalhes.

É razoável supor que, ao menos nas barganhas internacionais de dois níveis, o negociadorchefe normalmente priorizará seu cálculo doméstico, se uma escolha precisar ser feita, quando menos porque seu próprio emprego depende da sua posição no nível II. Assim, esse negociador é mais propenso a apresentar um acordo internacional para ratificação que signifique o menor investimento de capital político próprio para aprovação e que almeje o maior retorno político possível com a ratificação.

Essa concepção ampliada do papel do negociador-chefe implica que ele possui, efetivamente, o poder de veto sobre possíveis acordos. Mesmo se um acordo ficar dentro do seu conjunto de vitórias do nível II, é improvável que esse acordo seja fechado se ele opuser-se a ele ${ }^{49}$. Como essa cláusula aplica-se a ambos os lados do tabuleiro do nível I, o verdadeiro escopo do acordo alcançado no nível internacional pode ser mais estreito - talvez muito mais estreito - que a sobreposição

\footnotetext{
49 Esse poder do negociador-chefe é análogo ao que Shepsle e Weingast (1977) denominam de "penultimato" ou poder de veto ex post dos membros do Comitê Misto Câmara dos Deputados-Senado.
}

dos conjuntos de vitórias do nível II. Do ponto de vista empírico, essa restrição adicional é freqüentemente crucial para os resultados dos jogos de dois níveis. Um exemplo significativo nesse sentido é o do destino do Tratado de Versalhes. Em primeiro lugar, fortes evidências sugerem que talvez $80 \%$ do público estadunidense $e$ do Senado em 1919 apoiavam a ratificação do tratado caso certas restrições fossem adicionadas e, em segundo lugar, caso essas restrições fossem aceitas pelos demais signatários-chave, principalmente a GrãBretanha e a França. Com efeito, foi Wilson em pessoa quem vetou esse acordo ratificável, dizendo ao assombrado embaixador francês: "Eu não farei concessões em nada" (BAILEY, 1945, p. 15).

Uma outra restrição a uma negociação de dois níveis de sucesso deriva da coalizão doméstica existente de apoio ao líder. Qualquer empresário político tem um investimento fixo em determinado padrão de posições políticas e uma particular coalizão de apoio. Se um acordo internacional proposto ameaça esse investimento ou se a ratificação exige a constituição de uma coalizão diferente, o negociador-chefe relutará em endossá-lo, mesmo que (julgando abstratamente) ele pudesse vir a ser ratificado. Os políticos podem estar propensos a perder alguns de seus apoiadores normais no processo de ratificação de um acordo internacional, mas quanto maior for a perda potencial, maior será a sua relutância.

De fato, os custos fixos para constituir uma coalizão implicam a seguinte restrição ao conjunto de vitórias: quão grande deve ser o realinhamento das coalizões predominantes do nível II para ratificar uma proposta específica? Por exemplo, um acordo comercial pode aumentar as oportunidades de exportação do Vale do Silício, mas pode prejudicar a cidade de Aliquippa na Pensilvânia. Isso pode ser bom para determinado negociador-chefe (Reagan, por exemplo?) que pode facilmente adicionar os yuppies do Norte da Califórnia na sua coalizão de apoio e que não tem nenhuma esperança de ganhar o apoio dos trabalhadores do aço de Aliquippa. Mas outro negociador-chefe com uma coalizão de apoio diferente (Mondale, por exemplo?) pode achar bastante custoso ou mesmo impossível converter os ganhos do mesmo acordo em algo politicamente útil. Do mesmo modo, nas negociações de 1978 entre Bonn e Washington sobre o uso da "bomba de nêutrons", "pedir aos EUA que preparassem [essa arma] para usar na Alemanha Ocidental po- 
dia ser interessante para um governo Democrata Cristão, mas para um governo Social-Democrata era praticamente impossível" (STRONG \& ZERINGUE, 1986, p. 9). Sob tais circunstâncias, os modelos simples de "eleitor mediano" a respeito das influências domésticas sobre a política externa podem ser bastante enganosos.

Ao afrouxar o pressuposto segundo o qual o negociador-chefe é meramente um intermediário honesto que negocia em benefício de seus grupos domésticos, abre-se a possibilidade de que os grupos domésticos possam ser mais propensos a um acordo (ou mais preocupados com um "não acordo") do que o negociador. Exemplos empíricos não são difíceis de encontrar: no início de 1987 o público europeu estava mais disposto a aceitar a proposta de controle de armas "duplo zero" [double-zero] de Gorbatchev do que os líderes europeus, assim como no início dos anos 1970 o público estadunidense (ou pelo menos o público politicamente ativo) estava mais ansioso por um fim negociado da Guerra do Vietnã do que o governo Nixon. Como regra, o negociador mantém um poder veto sobre qualquer acordo proposto em tais casos. Entretanto, se a posição doméstica do negociador (ou mesmo seu próprio emprego) fosse ameaçada caso se ele tivesse que rejeitar um acordo condizente com os limites do seu conjunto de vitórias do nível II, e se isso fosse conhecido por todas as partes, então o outro lado no nível I ganharia considerável influência no processo. Os estadunidenses descontentes com a Guerra do Vietnã claramente afetaram o acordo obtido nas negociações de Paris ${ }^{50}$ (ZARTMAN, $1976 b$, p. 372-398). Inversamente, se os grupos domésticos são (percebidos como) linha-duras, a fraqueza doméstica de um líder torna-se um ativo diplomático. Por exemplo, em 1977 os estadunidenses calcularam que "a demora em negociar um tratado [...] colocou em perigo a posição de [Presidente panamenho Omar] Torrijos; um Panamá sem Torrijos teria sido, muito provavelmente, um parceiro com quem seria impossível de negociar" (Brzezinski apud HABEEB \& ZARTMAN, 1986, p. 39-40). Da mesma forma, nas negociações de Trieste de 1954 o fraco governo italiano sustentou que, "A não ser que alguma coisa seja feita em nosso favor em Trieste,

50 As negociações de Paris consistiram em reuniões de alto nível realizadas em 1973 e que resultaram na retirada das tropas estadunidenses do Vietnã, nesse mesmo ano (N. T.). podemos perder a eleição'. Essa carta foi utilizada duas ou três vezes [relatou mais tarde o negociador britânico] e quase sempre logrou resultado" (Harrison apud CAMPBELL, 1976, p. 67).

Minha ênfase na responsabilidade especial do poder Executivo central é um ponto de afinidade entre o modelo de jogos de dois níveis e a literatura estatocêntrica, embora a lógica subjacente difira. Nesse modelo "Jano" de interações entre o doméstico e o internacional, a política transnacional é menos proeminente que em certas teorias de interdependência (HUNTINGTON, 1973, p. 333368; cf. também NEUSTADT, 1970; KEOHANE \& NYE JR., 1977). Entretanto, desconsiderar as alianças transversais ["cross-table"] no nível II é uma simplificação considerável; isso é tão mais enganoso quanto menor for a visibilidade política do assunto e quanto mais freqüentes forem as negociações entre os governos envolvidos (CRANE, 1984). Empiricamente, por exemplo, os jogos de dois níveis na Comunidade Européia são influenciados por diversos laços diretos entre os participantes do nível II, como os porta-vozes nacionais da área agrícola. Em alguns casos, o mesmo ator multinacional de fato pode aparecer em mais de um tabuleiro do nível II. Em negociações sobre concessões de mineração em alguns países menos desenvolvidos, por exemplo, a mesma corporação multinacional pode ser consultada em privado tanto pelo governo de sua matriz como pelo governo da filial. Em trabalhos subseqüentes baseados no modelo de jogos de dois níveis, as implicações estratégicas da comunicação direta entre os diversos jogadores do nível II deveriam ser exploradas.

\section{CONCLUSÃO}

Em anos recentes o desenvolvimento mais portentoso das áreas de Política Comparada e de Relações Internacionais é o crescente reconhecimento entre os pesquisadores de cada área da necessidade de levar-se em consideração os entrelaçamentos entre ambos. Os exemplos empíricos da influência recíproca entre as questões domésticas e internacionais abundam. Precisamos agora de conceitos e teorias que ajudem a organizar e ampliar nossas observações empíricas.

As análises em termos de jogos de dois níveis oferecem uma resposta promissora para esse desafio. Diferentemente das teorias estatocêntricas, a abordagem de dois níveis reconhece a inevitabilidade do conflito doméstico em relação 
às exigências do "interesse nacional". Diferentemente das abordagens da "segunda imagem" e a da "segunda imagem invertida", a abordagem de dois níveis reconhece que os tomadores de decisão lutam para conciliar simultaneamente os imperativos domésticos e internacionais. Como observamos, os estadistas inseridos nessas difíceis situações encaram distintos dilemas e oportunidades estratégicos.

Essa abordagem teórica destaca diversas características importantes a respeito das ligações entre a diplomacia e a política doméstica, incluindo:

- a importante distinção entre as defecções voluntária e involuntária dos acordos internacionais;

- o contraste entre questões nas quais os interesses domésticos são homogêneos, simplesmente opondo falcões a pombos, e questões nas quais os interesses domésticos são mais heterogêneos, de tal modo que as divisões domésticas possam na verdade favorecer a cooperação internacional;

- a possibilidade de conexão sinérgica entre questões em que movimentos estratégicos em um tabuleiro facilitam coalizões inesperadas no outro tabuleiro;
- o fato paradoxal de que arranjos institucionais que fortalecem os tomadores de decisão domesticamente podem enfraquecer sua posição internacional de barganha e vice-versa;

- a importância de observar a influência dos tratados internacionais, das ofertas e das compensações paralelas sobre os planos domésticos do negociador-chefe e do outro país;

- o uso estratégico da incerteza sobre a política doméstica e a utilidade especial dos "conjuntos de vitórias incomuns";

- a potencial reverberação das pressões internacionais na arena doméstica e

- a divergência de interesses entre o líder nacional e aqueles em cujo benefício ele está negociando e, em particular, as implicações internacionais dos seus investimentos fixos na política doméstica.

Os jogos de dois níveis parecem ser um aspecto ubíquo da vida social, das cúpulas econômicas ocidentais à diplomacia nos Bálcãs, da política de coalizão no Sri Lanka às manobras legislativas no Congresso dos Estados Unidos. É necessário agora que pesquisas empíricas de longo alcance testem e aprofundem nossa compreensão sobre como esses jogos são disputados.

Robert D.Putnam (Robert_Putnam@ksg.harvard.edu) é Professor da Escola de Governo John F. Kennedy da Universidade de Harvard (Estados Unidos).

\section{REFERÊNCIAS BIBLIOGRÁFICAS}

ALLISON, G. T. 1971. Essence of Decision: Explaining the Cuban Missile Crisis. Boston: Little Brown.

ALT, J. E. 1987. Crude Politics: Oil and the Political Economy of Unemployment in Britain and Norway, 1970-1985. British Journal of Political Science, London, v. 17, p. 149-199, Apr.

ALT, J. E. \& EICHENGREEN, B. 1989. Parallel and Overlaping Games. Theory and An Application to the European Gas Trade. Economics \& Politics, London, v. 1, n. 2, p. 119-144, July.
ARTIS, M. \& OSTRY, S. 1986. International Economic Policy Coordination. Chatham House Papers n. 30. London: Routledge.

AXELROD, R. 1984. The Evolution of Cooperation. New York: Basic.

1987. The Gamma Paradigm for Studying the Domestic Influence on Foreign Policy. Artigo apresentado Reunião Annual da International Studies Association. Manuscrito.

BAILEY, T. A. 1945. Woodrow Wilson and the Great Betrayal. New York: MacMillan. 
BERNHEIM, R. D. \& WHINSTON, M. D. 1986. Common Agency. Econometrica, v. 54, p. 932942, July.

CAMPBELL, J. C. (ed.). 1976. Successful Negociation: Trieste 1954. Princeton: Princeton University.

CANZONERI, M. E. \& GRAY, J. A. 1983. Two Essays on Monetary Policy in an Independent World. International Finance Discussion Paper n. 219. Washington, D. C.: Federal Reserve System.

CARTER, J. 1985. Keeping Faith: Memoirs of A President. New York: Bantam.

CONYBEARE，J. 1985. Trade Wars: A Comparative Study of Anglo-Hanse, FrancoItalian, and Hawley-Smoot Conflicts. World Politics, Cambridge, Mass., v. 38, n. 1, p. 147172, Oct.

COOPER, R. N. 1986. International Cooperation in Public Health as a Prologue to Macroeconomic Cooperation. Brookings Discussion Papers in International Economics n. 44. Washington, D. C.: Brookings Institution.

CRANE, B. 1984. Policy Coordination by Major Western Powers in Bargaining with the Third World: Debt Relief and the Common Fund. International Organization, Boston, v. 38, p. 399-428, Summer.

CRAWFORD, V. P. 1982. A Theory of Disagreement in Bargaining. Econometrica, v. 50, p. 607-637, May.

DABAT, A. \& LORENZANO, L. 1984. Argenti$n a$ : The Malvinas and the End of Military Rule. London: Verso

DENZAU, A.; RIKER, W. \& SHEPSLE, K. 1985. Farquharson and Fenno: Sophisticated Voting and Home Style. American Political Science Review, Washington, D. C., v. 79, n. 4, p. 1117 1134, Dec.

DESTLER, I. M. \& MITSUYU, H. 1982. Locomotives in Different Tracks: Macroeconomics Diplomacy, 1977-1979. In: DESTLER, I. M. \& SATO, H. (eds.). Coping with U.S.-Japanese Economic Conflicts. Lexington, Mass.: Health.

DESTLER, I. M.; FUKUI, H. \& SATO, H. 1979. The Textile Wrangle: Conflict in Japanese-
American Relations, 1969-1971. Ithaca: Cornell University.

DEUTSCH, K. W. (ed.). 1957. Political Community in the North Atlantic Area: International Organization in the Light of Historical Experience. Princeton: Princeton University.

DRUCKMAN, D. 1978. Boundary Role Conflict: Negotiation and Dual Responsiveness. In: ZARTMAN, I. W. (ed.). The Negotiation Process: Theories and Applications. Beverly Hills: Sage.

EVANS, P. B. 1979. Dependent Development: The Alliance of Multinational, State, and Local Capital in Brazil. Princeton: Princeton University.

FROHN, J. \& ATAEGLIN, R. (eds.). 1980. Empirische Wirtschaftsforschung. Berlin: Duncker-Humblot.

GOUREVITCH, P. 1978. The Second Image Reversed: The International Sources of Domestic Politics. International Organization, Boston, v. 32, n. 4, p. 881-911, Fall.

. 1986. Politics in Hard Times: Comparative Response to International Economic Crisis. Ithaca: Cornell University.

HAAS, E. B. 1958. The Uniting of Europe: Political, Social, and Economic Forces, 19501957. Stanford: Stanford University.

1980. Why Collaborate? Issue-Linkage and International Regimes. World Politics, Washington, D. C., v. 32, n. 3, p. 357-405, Apr.

HABEED, W. M. \& ZARTMAN, I. W. 1986. The Panama Canal Negotiations. Washington, D. C.: Johns Hopkins Foreign Policy Institute.

HAGGARD, S. \& SIMMONS, B. 1987. Theories of International Regimes. International Organization, Boston, v. 41, n. 3, p. 491-517, Summer.

HASTINGS, M. \& JENKINS, S. 1984. The Battle for the Falklands. New York: Norton.

HENNING, C. R. 1987. Macroeconomic Diplomacy in the 1980s: Domestic Politics and International Conflict Among the United States, Japan, and Europe. Atlantic Paper n. 65. New York: Atlantic Institute for International Affairs.

HILLMAN, J. R. 1980. The Mutual Influence of Italian Domestic Politics and the International 
Monetary Fund. The Fletcher Forum 4, p. 122, Winter.

HISS, D. 1980. Welwirtschaftsgipfel: Betrachtungen eines Insiders (World Economics Summit: Observations of an Insider). In: FROHN, J. \& ATAEGLIN, R. (eds.). Empirische Wirtschaftsforschung. Berlin: Duncker-Humblot.

HOLLICK, A. L. 1981. U. S. Foreign Policy and the Law of the Sea. Princeton: Princeton University.

HOMER, T. \& ROSENTHAL, H. 1978. Political Resource Allocation, Controlled Agendas, and the Status Quo. Public Choice, v. 33, n. 4, p. 27-44.

HUNTINGTON, S. P. 1973. Transnational Organizations in Word Politics. World Politics, Washington, D. C., v. 25, n. 3, p. 333-368, Apr.

IKENBERRY, I. G. 1988. Market Solutions for State Problems: The International and Domestic Politics of American Oil Decontrol. International Organization, Boston, v. 42, n. 1, p. 151-177, Winter.

KATZENSTEIN，P. J. 1976. International Relations and Domestic Structure: Foreign Economic Policies of Advanced Industrial States. International Organization, Boston, v. 30, n. 1., p. 1-45, Winter.

(ed.). 1978. Between Power and Plenty: Foreign Economic Policies of Advanced States. Madison: University of Wisconsin.

1985. Small Sates in World Market: Industrial Policy in Europe. Ithaca: Cornell University.

KAUFMAN，R. R. 1985. Democratic and Authoritarian Responses to the Debt Issue: Argentina, Brazil, Mexico. International Organization, Boston, v. 39, n .3, p. 473-503, Summer.

KEOHANE, R. O. 1984. After Hegemony: Cooperation and Discord in the World Political Economy. Princeton: Princeton University.

KEOHANE, R. O. \& NYE JR., J. S. 1977. Power and Interdependence. Boston: Little, Brown.

KISSINGER, H. A. 1969. Domestic Structure and Foreign Policy. In: ROSENAU, J. N. (ed.).
International Politics and Foreign Policy. New York: Free.

KRASNER, S. D. 1978a. Defending the National Interest: Raw Materials Investments and U. S. Foreign Policy. Princeton: Princeton University.

1978b. United States Commercial and Monetary Policy: Unravelling the Paradox of External Strength and Internal Weakness. In: KATZENSTEIN, P. J. (ed.). Between Power and Plenty: Foreign Economic Policies of Advanced States. Madison: University of Wisconsin.

LAKE, D. A. 1984. The State as Conduit: The International Sources of National Political Action. Artigo apresentado no encontro anual da American Political Science Association. Manuscrito.

MESQUITA, B. B.; NEWMAN, D. \& RABUSHKA, A. 1985. Forecasting Political Events: The Future of Hong Kong. New Haven: Yale University.

MILNER, H. 1987. Resisting the Protectionism Temptation: Industry and the Making of Trade Policy in France and the United States during the 1970s. International Organization, Boston, v. 41, n. 4, p. 639-65, Autumn.

MITNICK, B. M. 1986. The Theory of Agency and Organizational Analysis. Artigo apresentado no encontro anual da American Political Science Association. Manuscrito.

MOE, T. M. 1984. The New Economics of Organization. American Journal of Political Science, Washington, D. C., v. 28, n. 4, p. 739-777, Nov.

NEUSTADT, R. E. 1970. Alliance Politics. New York: Columbia University.

PRATT, J. W. \& ZECKHAUSER, R. J. (eds.). 1985. Principal and Agents: The Structure of Business. Boston: Harvard Business School.

PRUITT, D. G. 1981. Negotiation Behavior. New York: Academic.

PUTNAM, R. D. \& BAYNE, N. 1987. Hanging Together: Cooperation and Conflict in the Seven-Powers Summits. Cambridge, Mass.: Harvard University.

PUTNAM, R. D. \& HENNING, C. R. 1986. Bonn Summit of 1978: How Does International 
Economic Policy Coordination Actually Work? Brookings Discussion Papers in International Economic n. 53. Washington, D. C.: Brookings Institution.

RAIFFA, H. 1982. The Art and Science of Negotiation. Cambridge, Mass.: Harvard University.

ROGOFF, K. 1985. Can International Monetary Policy Cooperation be Counterproductive? Journal of International Economics, v. 18, n. 3-4, p. 199-217, May. Disponível em: http:// www.economics.harvard.edu/files/faculty/ 51_JIE1985.pdf. Acesso em: 24.maio.2010.

ROSENAU, J. N. (ed.). 1969b. International Politics and Foreign Policy. New York: Free.

1969a. Toward the Study of National-International Linkages. In:__. Linkage Politics: Essay on the Convergence of National and International Systems. New York: Free.

. 1973. Theorizing Across Systems: Linkage Politics Revisited. In: WILKENFELD, J. (ed.). Conflict Behavior and Linkage Politics. New York: D. McKay.

ROSENBAUM, D. E. 1986. Sweeping Tax Bill Approved in House by 292-136 Margin. New York Times, Sept $26^{\text {th }}$.

SCHELLING, T. C. 1960. The Strategy of Conflict. Cambridge, Mass.: Harvard University.

SEBENIUS, J. K. 1984. Negotiating the Law of the Sea. Cambridge, Mass.: Harvard University.

SHARPF, F. 1987. A Game Theoretical Interpretation of Inflation and Unemployment in Western Europe. Journal of Public Policy, Cambridge, v. 7, n. 3, p. 227-257, July-Sept.

SHEPSLE, K. A. 1986. Cooperation and Institutional Arrangements. Artigo apresentado na Harvard Conference on International Regimes and Cooperation, Dedham, Mass., Feb. $13^{\text {th }}-15^{\text {th }}$. Disponível em: http://dlc. dlib.indiana.edu/dlc/bitstream/handle/10535/ 5476/cooperation $\% 20$ and $\% 20$ institutional $\% 20$ arrangements.pdf? sequence $=1$. Acesso em: 24.maio. 2010

SHEPSLE, K. A. \& WEINGAST, B. R. 1987. The Institutional Foundations of Committee
Power. American Political Science Review, Washington, D. C., v. 81, n. 1, p. 85-104, Mar.

SNIDAL，D. 1985. The Game Theory of International Politics. World Politics, Washington, D. C., v. 38 , n. 1, p. 25-57, Oct.

SNYDER, G. H \& DIESING, P. 1977. Conflict Among Nations: Bargaining, Decision Making, and System Structure in International Crisis. Princeton: Princeton University.

SPAVENTA, L. 1983. Two Letters of Intent: External Crisis and Stabilization Policy, Italia, 1973-77. In: WILLIAMSON, J. (ed.). IMF Conditionality. Washington, D. C.: Institute for International Economics.

STRAUS, R. S. 1987. Foreword. In: TWIGGS, J. E. (ed.). The Tokyo Round of Multilateral Trade Negotiations: A Case Study in Building Domestic Support for Diplomacy. Washington, D. C.: Georgetown University Institute for the Study of Diplomacy.

STRONG, R. A. \& ZERINGUE, M. 1986. The Neutron Bomb and the Atlantic Alliance. Artigo apresentado no encontro anual de 1986 da American Political Science Association.

TAKASHI, I. 1970. Conflicts and Coalition in Japan, 1930: Political Groups and the London Naval Disarmament Conference. In: GROENNINGS, S. (ed.). The Study of Coalition Behavior. New York: Holt, Rinehart \& Winston.

TATSUO, K. 1984. The London Naval Treaty, 1930. In: MORLEY, J. W. (ed.). Japan Erupts: The London Naval Conference and the Manchurian Incident, 1928-1932. New York: Columbia University.

THE SUNDAY TIMES INSIGHT TEAM. 1982. The Falklands War. London: Sphere.

TSEBELIS, G. 1988. Nested Games: The Cohesion of French Coalitions. British Journal of Political Science, London, v. 18, n. 2, p. 145-170, Apr.

TWIGGS, J. E. (ed.). 1987. The Tokyo Round of Multilateral Trade Negotiations: A Case Study in Building Domestic Support for Diplomacy. Washington, D. C.: Georgetown University Institute for the Study of Diplomacy. 
VAUBEL, R. 1986. A Public Choice Approach to International Organization. Public Choice, v. 51, p. 39-57. Disponível em: http://www.axeldreher.de/Vaubel\%201986\%20PC.pdf. Acesso em: 24.maio.2010.

WALTON, R. E. \& MCKERSIE, R. B. 1965. A Behavioral Theory of Labor Negotiations: An Analysis of a Social Interaction System. New York: McGraw-Hill.

WALTZ, K. N. 1959. Man, the State, and War: Theorethical Analysis. New York: Columbia University.

WILSON, J. Q. 1975. Political Organization. New York: Basic.

WINHAM，G. R. 1977. Complexity in International Negotiation. In: DRUCKMAN, D. (ed.). Negotiations: A Social-Psychological Perspective. Beverly Hills: Sage.
1980. Robert Straus, the MTN, and the Control of Faction. Journal of World Trade Law, n. 14, p. 377-397, Sept.-Oct.

. 1986. International Trade and Tokyo Round Negotiations. Princeton: Princeton University.

1987. The Relevance of Clausewitz to a Theory of International Negotiation. Artigo apresentado no Encontro Anual da American Political Science Association. Manuscrito.

ZARTMAN, I. W. 1976a. The 50\% Solution. Garden City: Anchor.

. 1976b. Reality, Image, and Detail: The Paris Negotiation, 1969-1973. In: . The $50 \%$

Solution. Garden City: Anchor. 1978. Responsiveness. In: (ed.). The Negotiation Process: Theories and Applications. Beverly Hills: Sage.

\section{OUTRAFONTE}

World Politics. 1985. Washington, D. C., v. 38, Oct. Special issue: "Cooperation Under Anarchy". 
DIPLOMACY AND DOMESTIC POLITICS: THE LOGIC OF THE TWO-LEVEL GAMES

Robert Putnam

Domestic politics and international relations are often inextricably entangled, but existing theories (particularly state-centric theories) do not adequately account for these linkages. When national leaders must win ratification (formal or informal) from their constituents for an international agreement, their negotiating behavior reflects the simultaneous imperatives of both a domestic political game 
and an international game. Using illustrations from Western economic summitry, the Panama Canal and Versailles Treaty negotiations, IMF stabilization programs, the European Community, and many other diplomatic contexts, this article offers a theory of ratification. It addresses the role of domestic preferences and coalitions, domestic political institutions and practices, the strategies and tactics of negotiators, uncertainty, the domestic reverberation of international pressures, and the interests of the chief negotiator. This theory of "two-level games" may also be applicable to many other political phenomena, such as dependency, legislative committees, and multiparty coalitions.

KEYWORDS: two-level games; negotiations; foreign policy; domestic policy; diplomacy. 


\section{LA DIPLOMATIE ET LA POLITIQUE INTÉRIEURE : LA LOGIQUE DU JEU DE DEUX NIVEAUX}

\section{Robert D. Putnam}

La politique intérieure et les relations internationales sont souvent inextricablement liées ; cependant, les théories éxistentes (particulièrement celles qui sont «État - centriques »), ne prennent pas suffisamment en considération ces liens. Quand les dirigeants nationaux doivent obtenir les ratifications (formelles ou informelles), des membres de leurs parlements pour un accord international, leurs comportements pendant les négociations reflètent les imperatifs simultanés, bien d'un jeu de politique intérieure, comme d'un jeu de politique internationale. En utilisant des exemples de coupoles économiques occidentales, des négociations du Canal de Panamá et du Traité de Versailles, des programmes de stabilisation du Fonds Monétaire International, de la Communauté Européenne et d'autres nombreux contextes diplomatiques, l'article offre une théorie de la ratification. Il souligne le rôle des préférences, coalitions, institutions et pratiques nationales, des stratégies et tactiques des négociateurs, de l'incertitude, des réverbérations internes, des pressions extérieures et le rôle des intérêts du négociateur en chef. Cette théorie de " jeux de deux niveaux » peut aussi être apliquée à beaucoup d'autres phenomènes politiques, comme la dépendence, les comités législatifs et les coalitions multipartites.

MOTS-CLES: jeux de deux niveaux; négociations; politique intérieure; politique extérieure; diplomatie. 